Portland State University

PDXScholar

$1-1-2010$

\title{
Nihilism Unbound: Strauss, Nietzsche and Foucault as Nihilist Thinkers
}

Jeffrey Jacob Wade

Portland State University

Follow this and additional works at: https://pdxscholar.library.pdx.edu/open_access_etds Let us know how access to this document benefits you.

\section{Recommended Citation}

Wade, Jeffrey Jacob, "Nihilism Unbound: Strauss, Nietzsche and Foucault as Nihilist Thinkers" (2010). Dissertations and Theses. Paper 396.

https://doi.org/10.15760/etd.396

This Thesis is brought to you for free and open access. It has been accepted for inclusion in Dissertations and Theses by an authorized administrator of PDXScholar. Please contact us if we can make this document more accessible: pdxscholar@pdx.edu. 


\title{
Nihilism Unbound:
}

Strauss, Nietzsche and Foucault as Nihilist Thinkers

\author{
by \\ Jeffrey Jacob Wade
}

A thesis submitted in partial fulfillment of the requirements for the degree of

\author{
Master of Arts \\ in \\ Political Science
}

\author{
Thesis Committee: \\ Craig L. Carr, Chair \\ Bruce Gilley \\ Birol Yeşilada
}

Portland State University

(C)2010 
Abstract

Many of the writings of Leo Strauss were dedicated to combating the "crisis of modernity". This crisis was for him the advent and acceptance of nihilism-a state of being wherein any principle one dare dream is allowed and judgment must be withheld. He claimed that the promotion of nihilism at the hands of modern social scientists would lead to the downfall of civilization. Yet, this work seeks to show that all of these claims are made by Strauss in an attempt to hide the "truth" of nihilism from the masses and that Strauss, in fact, is a nihilist thinker.

The introductory chapter of this work introduces the problem of nihilism as outlined by Strauss. It also briefly explains the positions of two other nihilist thinkers, Friedrich Nietzsche and Michel Foucault, in order to establish the thought which Strauss seems to be arguing against in his works. It then explains the writing style of Strauss as being esoteric.

The following chapter will deal with the Strauss' argument for the causes of nihilism. Chapter three will be dedicated to the two solutions that Strauss presents for combating nihilism. The exoteric solution calls for a return to the teachings of the classics, specifically the three types of teaching that he recognizes-Socratic-Platonic, Aristotelian, and Thomistic. The esoteric solution, however, is to use the Platonic conception of the "noble lie" in order to hide the "truth" of nihilism.

Chapters four and five will compare Strauss' nihilism to that of Nietzsche and Foucault, respectively. Each chapter will expand on the discussion already presented in the first chapter to further elucidate each thinker's version of nihilism. 
Finally, I will outline the conception of these three thinkers as a continuum for nihilist thought. I will also discuss how the only definitive difference between the three thinkers is their outlook on the human condition. For example, Strauss and his hidden nihilism is a direct result of his pessimistic view of the masses; whereas Nietzsche's Übermensch nihilism is brought about by his outlook on the prospect for development beyond humanity and Foucault's pure nihilism is drawn out from his notion of power/knowledge. In this way, this work will not only show Strauss as a closet nihilist but also show his integral role in understanding the full range of nihilist thought. 
Table of Contents

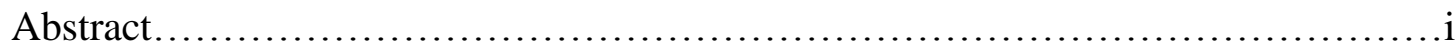

Chapter 1 - The Crisis of Modernity .......................................

Chapter 2 - The Two-Fold Rejection of Natural Right.........................11

Chapter 3 - Strauss' Solutions..............................................23

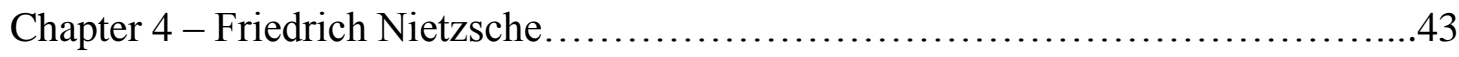

Chapter 5 - Michel Foucault...............................................63

Chapter 6 - Conclusion................................................ 74

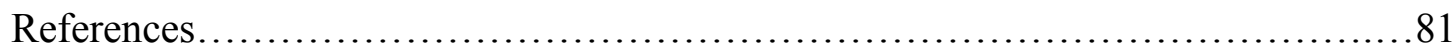


Chapter 1 - The Crisis of Our Time

In Natural Right and History, ${ }^{1}$ Leo Strauss presents an argument that American political thought is following in the path of German thought — a path he deems dangerous for the preservation of Western civilization. This path involves the rejection of the idea of natural right in favor of adopting an unqualified relativism. "Present-day American social science... is dedicated to the proposition that all men are endowed by the evolutionary process or by a mysterious fate with many kinds of urges and aspirations, but certainly with no natural right." ${ }^{2}$ Without natural right, Strauss believes that all that remains is positive right. That is to say, what is right is that which is adopted by one's society.

If this is the case, then it is impossible for one to justify their principles over any other principles. "[T] he principles of cannibalism are as defensible or sound as those of civilized life... the former principles can certainly not be rejected as simply bad." 3 The only obstacle between a society and the adoption of the cannibalism is habit. For Strauss, this precarious situation stems from the contemporary rejection of natural right—-something he equates with nihilism.

\section{Two Nihilist Thinkers}

What, then, is nihilism? As Strauss describes, it is a situation wherein "everything a man is willing to dare will be permissible." It is a situation wherein no one principle can be judged as being good or being bad. He saw nihilism as nothing less than "the [conscious] rejection of the principles of civilisation as such... [and b]y

\footnotetext{
${ }^{1}$ Strauss, Natural Right and History.

${ }^{2}$ Ibid. 2.

${ }^{3}$ Ibid. 3 .

${ }^{4}$ Ibid. 4-5.
} 
civilisation, [he understood] the conscious culture of humanity, i.e. of that which makes a human being a human being." ${ }^{, 5}$ A nihilist, then, rejects the principles that historically have made individuals. What was once deemed a natural condition of man is for the nihilist so much hot air. To further elucidate this definition, two thinkers who present just such an argument, Friedrich Nietzsche and Michel Foucault, shall be examined.

\section{Friedrich Nietzsche}

Nietzsche, like so many philosophers before him, sought to identify what it means to be human. "For Nietzsche, however, this existential questioning about human identity cannot be separated from an understanding of history (especially of morality), of culture, and of politics." ${ }^{, 6}$ But how is Nietzsche a nihilist? The answer can be found within the answers he found in his existential queries.

What he found was that those of the modern age needed to experience nihilism "in order to find out what value [their] "values' really had.", This conclusion stems from his perspectivist analysis of the history of metaphysics and morality. By "perspectivist analysis", one is referring to the view that Nietzsche holds through much of his work, "that 'truths' are one and all interpretations formulated from particular perspectives." ${ }^{8}$ This view, however, can be interpreted in one of two ways. The first interpretation sees Nietzsche's perspectivism as a "brand of neo-Kantianism that simply spells out the implication of Kant's theory that the world as it appears to us

\footnotetext{
${ }^{5}$ Strauss, "German Nihilism", 364-5.

${ }^{6}$ Ansell-Pearson, An Introduction to Nietzsche as Political Thinker, 1.

${ }^{7}$ Ibid. 37.

${ }^{8}$ Magnus and Higgins, "Nietzsche's works and their themes", 31-2.
} 
is constructed by our particular human faculties." 9 This work rejects such an interpretation since it seems to contradict Nietzsche's critique of metaphysics, which he saw as devaluing earthly life in favor of promoting the existence of a "real" world outside of experience.

The second interpretation reads "Nietzsche's perspectivism as a radical form of relativism, one which denies any basis for preferring one perspective to another." ${ }^{10}$ It is this second interpretation that this work follows. First, it fits more in line with the rest of Nietzsche's work. Secondly, it also shows his tendency towards nihilism, since it rejects the possibility of "eternal facts" or "objective truths". In this way, the second interpretation of perspectivism gives Nietzsche reason to reject the "principles of civilization" and adopt nihilism.

A more expansive look at Nietzsche's perspectivism and how it leads to his version of nihilism shall be reserved for later in the work. For now, it is only necessary to understand that it is his rejection of "truths" and perspectivist focus on history that Strauss would use to accurately denote him as a nihilist.

\section{Michel Foucault}

Foucault also examines the human condition through the study of history in a manner very similar to Nietzsche's perspectivism. Where Nietzsche tried to find the value of "values", however, Foucault was more concerned "with what knowledge does, what power constructs (rather than represents) and how a relationship of the self

\footnotetext{
${ }^{9}$ Ibid. 32 .
}

${ }^{10}$ Ibid. 
to the self is invented rather than discovered."11 In other words, he attempted to explain history from the perspective of history, but unlike Nietzsche, he refused to sit in judgment of the various perspectives.

Regardless of this difference, Foucault is still a nihilist. His process shows that human nature is variable, "not because we repress our true natures, nor because our true natures are repressed by our parents, our leaders, or our culture, but because we do not have true natures." ${ }^{\prime 2}$ In this way, he rejected the principles of civilization that Strauss claims make human beings human. Again, it is not necessary to fully understand Foucault's work at this moment. It is only necessary to recognize that his theories lead to nihilism as Strauss has identified it by denying "natural conditions" for “inventions of history".

\section{Origin of the Crisis}

For Strauss, there are two means by which one can come to be a nihilist — "in the name of History and in the name of the distinction between Facts and Values."13 In other words, the paths to nihilism are historicism and value-neutrality.

\section{Historicism}

According to historicists, "all human thought is historical and hence unable to grasp anything eternal."14 That is to say, one cannot stand outside the human experience to locate "truth". This is similar to Nietzsche's perspectivism, which

\footnotetext{
${ }^{11}$ Lamber and Smeyers, "Nihilism: Beyond Optimism and Pessimism", 187.

12 Ibid. 188. (Italics added)

${ }^{13}$ Strauss, Natural Right and History, 8.

${ }^{14}$ Ibid. 12.
} 
"recognises the conditionality of human forms of knowledge and is not concerned with absolutes." ${ }^{.15}$

It is also similar to Foucault's rejection of the theme of a "continuity of history". Foucault rejected the view of history:

that would be not division, but development (devenir); not an interplay of relations, but an internal dynamic; not a system, but the hard work of freedom; not form, but the unceasing effort of a consciousness turned upon itself, trying to grasp itself in its deepest conditions: a history that would be both an act of long, uninterrupted patience and the vivacity of a movement, which, in the end, breaks all bounds. ${ }^{16}$

In other words, he adopts a stance that rejects the notion that conditions of the present are a necessary consequence of historical development. In its place, "Foucault's histories aim to remove this air of necessity by showing that the past ordered things quite differently and that the processes leading to our present practices... were by no means inevitable. ${ }^{117} \mathrm{He}$ rejects the position of historian as outside observer in order to adopt the position of historian as subjective interpreter-interpreting the present in terms of the past.

The historicist's rejection of eternal "truth" leads to nihilism for Strauss, then, precisely because it denies the possibility on knowing the principles of man as such, or simply denies the possibility of such principles. A historicist can only know the principles of man in history—only as man knows himself to be at that time. There are no universals, just the "blind preferences" of one's time.

\footnotetext{
${ }^{15}$ Ansell-Pearson, An Introduction to Nietzsche as Political Thinker, 16.

${ }^{16}$ Foucault, The Archaeology of Knowledge, 13.

${ }^{17}$ Gutting, The Cambridge Companion to Foucault, 10.
} 
Value-Neutrality

According to Strauss, value-neutrality leads to nihilism by eliminating the possibility of objective norms. ${ }^{18}$ Though Strauss uses Max Weber as an example in his discussion of value-neutrality, he is not the only thinker who claimed "that there is no hierarchy of values: [that] all values are of the same rank. ${ }^{, 19}$ Looking at the two nihilists already mentioned, it is possible to see that both adhere to this idea as well if not explicitly stated.

Foucault was more explicit than Nietzsche in this regard. Yet, both are led to their positions of value-neutrality through their adoption of historicism. For Nietzsche, value-neutrality is similar to the notion of revaluating all values. "The notion of revaluating all values is perplexing[, however]; evaluation occurs in terms of some value, while Nietzsche allegedly wants to call all values into question." ${ }^{20}$ It is this questioning of all values that implies that even the values held by the evaluator must be held in revaluation. In this way, no value is worth more than another.

For Foucault, value-neutrality stems from his conception of power/knowledge, which is a complex concept that establishes knowledge as being interlinked with the power structures acting upon the "knowledge-bearer". As he puts it:

We should admit... that power produces knowledge (and not simply by encouraging it because it serves power or by applying it because it is useful); that power and knowledge directly imply one another; that there is no power relation without the correlative constitution of a field of knowledge, nor any knowledge that does not presuppose and constitute at the same time power relations. $^{21}$

\footnotetext{
${ }^{18}$ Strauss, Natural Right and History, 70.

${ }^{19}$ Ibid. 66.

${ }^{20}$ Magnus and Higgins, "Nietzsche's works and their themes", 54.

${ }^{21}$ Foucault, Discipline and Punish, 27.
} 
Any type of knowledge corresponds to a power relation-medical science with the doctor and patient or the doctor and societal expectations, for example.

This notion leads him to claim that "[t]ruth is a thing of this world: it is produced only by virtue of multiple forms of constraint... Each society has its regime of truth, its 'general politics' of truth." 22 Values, then, are a product of power relations that have developed through history. Since these power relations are not necessary developments but merely the path that has occurred, ${ }^{23}$ no value can be ranked as better or worse than any other value.

For Strauss, then, nihilism stems from one's rejection of value judgments. Not merely the rejection of some value judgments but the rejection of the possibility of any value judgments. Without the possibility of value judgments, "everything a man is willing to dare [is] permissible."24

\section{Strauss' Solution as a Form of Nihilism}

Yet, despite these protestations against nihilism, it is the objective of this paper to show that Strauss is himself a nihilist thinker - one separate from both Nietzsche and Foucault. If one thinks of nihilist thinkers lying on a continuum, Nietzsche would take one end as an optimistic nihilist in terms of his outlook on the consequences of nihilism. Foucault would fall in the dead center as a "pure" nihilist, since he sees no impact on humanity stemming from the knowledge of nihilism. Strauss, it will be argued, takes his place at the other end of the spectrum as a pessimistic nihilist. He

\footnotetext{
${ }^{22}$ Foucault, Power/Knowledge, 131.

${ }^{23}$ Ibid.

${ }^{24}$ Strauss, Natural Right and History, 4-5.
} 
sees nihilism as a truth but one that cannot be known to humanity in general for fear of the resultant chaos.

In order to achieve the goal of this paper, it is necessary to first take note of Strauss' esoteric writing style. After this style is explained, the remainder of this chapter will outline how this paper will proceed to explain Strauss' position as a nihilist thinker.

\section{A Note on Strauss' Method}

While it is not an entirely accepted argument, ${ }^{25}$ this paper adopts the viewpoint that Strauss follows an esoteric method of writing. In this method, an author puts forward a popular argument of the time — say, "all men are created equal"- but argues "between the lines" for the rejection of such a notion. The purpose of which is to protect the author from the potentially violent reprisal of society at large.

Strauss describes the need for this method in relation to "the quest for truth", stating:

Philosophy or science, the highest activity of man, is the attempt to replace opinion about "all things" by knowledge of "all things"; but opinion is the element of society; philosophy or science is therefore the attempt to dissolve the element in which society breathes, and thus endangers society. Hence philosophy or science must remain the preserve of a small minority, and philosophers or scientist must respect the opinions on which society rests. To respect opinions is something entirely different from accepting them as true. Philosophers or scientists who hold this view... are driven to employ a peculiar manner of writing which would enable them to reveal what they regard as true to the few, without endangering the unqualified commitment of the many to the opinions on which society rests. They will distinguish between the true teaching as the esoteric teaching and the socially useful teaching as the exoteric teaching. ${ }^{26}$

\footnotetext{
${ }^{25}$ See Chapter 3, Esoteric Solution for more information about the debate on Strauss' writing style and why other suggestions are rejected.

${ }^{26}$ Strauss, What Is Political Philosophy?, 221-2.
} 
It is by using this hermeneutic that Strauss revolutionized the study of the history of philosophy. With it, he claims to have rediscovered the meaning behind many of the classic works - from Plato to Locke. He also, it will be argued, ${ }^{27}$ used the method himself to hide his true intent. That is to say, that while he exoterically argued against the promotion of nihilism, he esoterically argued for the adoption of the nihilist standpoint.

Why would he go through the trouble to use such a perplexing writing style?

The answer can be found by examining what he thought would happen if the opinions of society were abandoned. He feels that allowing an individual to abandon the opinion of society also allows that individual to adopt any principle he sees fit. He also feared that society may react against the scholar who opposed the opinion of society.

It is required of this paper to bring Strauss' esoteric teachings out into the open to show his defense of nihilism. Why throw away the obvious precautions that Strauss took to hide his true meaning? Like the Straussian scholar, S. B. Drury, I am "unconvinced that philosophical truth is as terrible and as dangerous to society as he believes it to be. ${ }^{, 28}$ But that argument must wait for the final chapter.

\section{A Note on this Work}

On that note, it has become necessary to outline the argument that this paper will take. Having outlined, here, the basic concepts upon which this paper will build, the next chapter will deal with the exoteric Strauss and his argument for the causes of

\footnotetext{
${ }^{27}$ See Chapter 3.

${ }^{28}$ Drury, "The Esoteric Philosophy of Leo Strauss", 315.
} 
nihilism. It will be necessary for the reader to keep in mind what Strauss is arguing against here and recognize that he does so for what he believes is the benefit of society. I will be careful to allude to the esoteric teachings where appropriate and necessary but most of this discussion will take place in the third chapter.

Chapter three will be dedicated to the two solutions that Strauss presents for combating nihilism. The exoteric solution calls for a return to the teachings of the classics, specifically the three types of teaching that he recognizes-Socratic-Platonic, Aristotelian, and Thomistic. The esoteric solution, however, is to use the Platonic conception of the noble lie in order to hide his feeling about the "truth" of nihilism.

Chapters four and five will compare Strauss' nihilism to that of Nietzsche and Foucault, respectively. Each chapter will expand on the discussion already presented in this chapter to further elucidate each thinker's version of nihilism.

The final chapter will outline the conception of these three thinkers as a continuum for nihilist thought. It will also discuss how the only definitive difference between the three thinkers is their outlook on the human condition. For example, Strauss and his hidden nihilism is a direct result of his pessimistic view of the masses; whereas Nietzsche's Übermensch nihilism is brought about by his outlook on the prospect for development beyond humanity. In this way, this work will not only show Strauss as a closet nihilist but also show his integral role in understanding the full range of nihilist thought. 
Chapter 2 - The Two-Fold Rejection of Natural Right

The problem of nihilism stems from the rejection of natural right. For Strauss, this rejection is done "on two different, although mostly combined, grounds... in the name of History and in the name of the distinction between Facts and Values." ${ }^{1}$ In other words, natural right is rejected by historicism and value-neutrality. What follows is an analysis of Strauss' argument of how this rejection takes place.

\section{Historicism's Rejection of Natural Right}

The rejection of natural right in the name of history has to amount to more than the claim that history shows that no right is universally acknowledged for Strauss. ${ }^{2}$ Rather, the rejection of natural right made by historicism can only be understood when one understands 'the specific difference between 'conventionalism', on the one hand, and the 'historical sense'... characteristic of nineteenth- and twentieth-century thought, on the other." ${ }^{, 3}$ It is necessary, then, to examine this difference.

\section{Conventionalism}

As Strauss puts it, "[c] onventionalism presupposed that the distinction between nature an convention is the most fundamental of all distinctions. It implied that nature is of incomparably higher dignity than convention or the fiat of society, or that nature is the norm." "This line of thought is similar to that found in many classical thinkers' philosophies. In fact, Strauss claims ${ }^{5}$ that conventionalists argue "that the distinction

\footnotetext{
${ }^{1}$ Strauss, Natural Right and History, 8.

${ }^{2}$ Ibid. 9-10.

${ }^{3}$ Ibid. 10.

${ }_{5}^{4}$ Ibid. 11.

${ }^{5}$ A claim to which I am inclined to agree.
} 
between nature and convention is fundamental. For this distinction is implied in the idea of philosophy."6

In this view, to borrow a metaphor from Plato, ${ }^{7}$ philosophy is the means by which one ascends from the cave of convention (or opinion) and into the light of truth (or understanding of nature). "Men cannot live... together, if opinions are not stabilized by social fiat. Opinion thus becomes authoritative opinion or public dogma... Philosophizing means, then, to ascend from public dogma to essentially private knowledge. ${ }^{, 8}$ In other words, it is through philosophy that one attains an ideal higher than that of society and can, then, achieve a critical distance from it. ${ }^{9}$ It is for this reason that Strauss wishes to return to conventionalism in order to prevent nihilism.

Yet, it must be kept in mind that this is the exoteric Strauss speaking. One must take note of how Strauss summarizes the idea of conventionalism to see his esoteric teaching.

The public dogma is originally an inadequate attempt to answer the question of the all-comprehensive truth or of the eternal order. Any inadequate view of the eternal order is, from the point of view of the eternal order, accidental or arbitrary; it owes its validity not to its intrinsic truth but to social fiat or convention. The fundamental premise of conventionalism is, then, nothing other than the idea of philosophy as the attempt to grasp the eternal. ${ }^{10}$

If public dogma is an inadequate attempt to glimpse the eternal order, then it becomes necessary to call into question Strauss' defense of natural right. This is especially true

\footnotetext{
${ }^{6}$ Strauss, Natural Right and History, 11.

${ }^{7}$ Plato, The Republic and Other Works, 208-10.

${ }^{8}$ Strauss, Natural Right and History, 12.

${ }^{9}$ Ibid. 3.

${ }^{10}$ Ibid. 12.
} 
when one considers the fact that he started his work by quoting the Declaration of Independence - one of the central documents to American public dogma. ${ }^{11}$ If Strauss is calling into question the public dogma he is exoterically defending, what is his true purpose? In order to show his true purpose, it is first necessary to examine the means by which he defends this public dogma.

\section{The Historical Sense}

Continuing forward, Strauss argues that "modern opponents of natural right reject [conventionalism]. According to them, all human thought is historical and hence unable ever to grasp anything eternal."12 This is the view of historicism. By understanding this view, one gains insight into how natural right must be rejected by it.

By examining history, a historicist believes that one will find that no objective norms can be found. "To the unbiased historian, 'the historical process' revealed itself as the meaningless web spun by what men did, produced, and thought, no more than by unmitigated chance - a tale told by an idiot." ${ }^{, 13}$ Without the possibility of an eternal order, an idiot's tale was all that remained of philosophy for historicism. The quests for objective truth led by classic philosophers become nothing more than the subjective opinions of those thinkers. All that remains is for individuals to choose which opinions they shall follow. "No objective criterion henceforth allowed the distinction between good and bad choices. Historicism culminated in nihilism."14

\footnotetext{
${ }^{11}$ Ibid. 1.

${ }^{12}$ Ibid. 12 .

${ }^{13}$ Ibid. 18.

${ }^{14}$ Ibid.
} 
Yet, this does not mean that there are no universal truths within the history of thought. Rather, history seems "to prove that all human thought, and certainly all philosophic thought, is concerned with the same fundamental problems, and therefore that there exists an unchanging framework which persists in all changes of human knowledge of both facts and principles." ${ }^{\prime 15}$ In other words, if human thought is capable of taking a trans-historical approach to these problems, it may be possible for it to take a trans-historical approach to their solution.

This, Strauss feels, historicism must grant as possible if it is to keep its own legitimacy. He argues this point by expressing how it would be possible for natural right to exist within this framework of human capabilities. "[T]here cannot be natural right if human thought is not capable of acquiring genuine, universally valid, final knowledge within a limited sphere or genuine knowledge of specific subjects. Historicism cannot deny this possibility." "If it were to deny the possibility of limited genuine knowledge, then it must also deny its own possibility. This is because, "[t]he historicist thesis is not an isolated assertion: it is inseparable from a view of the essential structure of human life. This view has the same trans-historical character or pretension as any natural right doctrine.",17

In this way, Strauss finds the historicist thesis to be absurd and incapable of legitimately rejecting doctrines of natural right. It "thrives on the fact that it inconsistently exempts itself from its own verdict about all human thought." ${ }^{18}$ Yet, he cannot claim to have saved natural right from its rejection based on historicism. This is

\footnotetext{
${ }^{15}$ Ibid. $23-4$.

${ }^{16}$ Ibid. 24.

${ }^{17}$ Ibid.

${ }^{18}$ Ibid. 25.
} 
due to the existence of radical historicism, which recovers the historicist thesis from its fatal inconsistency.

\section{Radical Historicism}

Radical historicism recovers the historicist thesis by rejecting its trans-

historical character. To understand how it does this, one has to understand how Strauss defines theoretical analysis.

Thought that recognizes the relativity of all comprehensive views has a different character from thought which is under the spell of, or which adopts, a comprehensive view. The former is absolute and neutral; the latter is relative and committed. The former is a theoretical insight that transcends history; the latter is the outcome of a fateful dispensation. ${ }^{19}$

Inconsistent historicism, then, is guilty of adopting a theoretical thesis on human thought, thereby making it trans-historical. The radical historicist, in order to save historicism, "denies... the possibility of a theoretical or objective analysis, which as such would be trans-historical, of the various comprehensive views or 'historical worlds' or 'cultures.",20

This position Strauss credits to Friedrich Nietzsche and his attack on nineteenth-century historicism. This attack had two aspects. "First, historicism's theoretical viewpoint endangers human life, because its analysis destroys 'the protecting atmosphere within which life or culture or action is alone possible.",21 That is to say, this viewpoint destroys the public dogma that is necessary for human society. "Second, the theoretical viewpoint, because it presumes to stand outside of life is

\footnotetext{
${ }^{19}$ Ibid.

${ }^{20}$ Ibid. 26.

${ }^{21}$ Lampert, Leo Strauss and Nietzsche, 6-7.
} 
inevitably a misunderstanding of life."22 By taking an objective stance—-by standing

'outside of life,' the theoretical viewpoint leads to misinterpretations.

For Strauss, this leaves Nietzsche in the precarious position of choosing

between two alternatives:

he could insist on the strictly esoteric character of the theoretical analysis of life - that is, restore the Platonic notion of the noble delusion — or else he could deny the possibility of theory proper and so conceive of thought as essentially subservient to, or dependent on, life or fate. ${ }^{23}$

Which Nietzsche chooses, Strauss leaves unanswered in this work. He claims only that "his successors adopted the second alternative." 24

In another work, "Note on the Plan of Nietzsche's Beyond Good and Evil", 25

Strauss expresses that he believes that Nietzsche would pick the latter as well. That is

to say, the esoteric Strauss argues as such. The exoteric Strauss starts the essay by

claiming that "in Beyond Good and Evil... in the contemporary preface to which

[Nietzsche] presents himself as the antagonist of Plato, he 'platonizes' as regards the

'form' more than anywhere else." ${ }^{26}$ Yet, later in the work Strauss writes:

One is tempted to say Nietzsche's pure mind grasps the fact that the impure mind creates perishable truths. Resisting that temptation we state Nietzsche's suggestion following him in this manner: the philosophers tried to get hold of the "text" as distinguished from "interpretations"; they tried to "discover" and not to "invent." What Nietzsche claims to have realized is that the text in its pure, unfalsified form is inaccessible... everything thought by anyone... is in

\footnotetext{
${ }^{22}$ Ibid. 7.

${ }^{23}$ Strauss, Natural Right and History, 26. It is also necessary to point out that Strauss is presenting himself with the choice he feels is necessary to recover natural right doctrines. He can either esoterically use them as a Platonic noble lie or he can accept the nihilist position exoterically. It will be argued in the next chapter that Strauss accepts the former solution over the latter.

${ }^{24}$ Ibid.

${ }^{25}$ Stauss, "Note on the Plan of Nietzsche's Beyond Good and Evil", 174-91.

${ }^{26}$ Ibid. 175 .
} 
the last analysis interpretation. But for this very reason the text... cannot be of any concern to us. ${ }^{27}$

In this way, the esoteric Strauss argues that Nietzsche paved the way for his successors by directing one to Nietzsche's own words: "It is nothing more than a moral prejudice that truth is worth more than semblance; it is in fact the worst proved supposition in the world." ${ }^{28}$ Or in the very next aphorism: "There is something ticklish in 'the truth,' and in the search for the truth; and if man goes about it too humanely... I wager he finds nothing!"29

It is obvious, then, that Nietzsche and his followers in radical historicism reject the possibility of theoretical insight in favor of adopting a view that is purely historical. They have redefined the historicist thesis such that "[a]11 understanding, all knowledge, however limited and 'scientific,' presupposes a frame of reference; it presupposes a horizon, a comprehensive view within which understanding and knowing take place." ${ }^{30}$ The comprehensive view that is mentioned in the radical historicist thesis should be recognized as the comprehensive view of its time - that is, a purely historical creation. "Accordingly, there is a variety of such comprehensive views, each as legitimate as any other: we have to choose such a view without any rational guidance." 31 Thus, the comprehensive view that the historicist thesis took

\footnotetext{
${ }^{27}$ Ibid. 177.

${ }^{28}$ Nietzsche, Beyond Good and Evil, 420.

${ }^{29}$ Ibid. 421.

${ }^{30}$ Strauss, Natural Right and History, 26.

${ }^{31}$ Ibid. 27.
} 
remains so for the radical historicist with the single caveat that "it does not transcend history [because] it belongs to a specific historic situation."32

\section{Effect of Rejection on Natural Right}

In order to recover natural right doctrines, then, from this rejection Strauss must identify the impact that this rejection has. As Strauss puts it:

Radical historicism compels us to realize the bearing of the fact that the very idea of natural right presupposes the possibility of philosophy in the full and original meaning of the term. It compels us at the same time to realize the need for unbiased reconsideration of the most elementary premises whose validity is presupposed by philosophy... Prior to such reconsideration, however, the issue of natural right can only remain an open question. ${ }^{33}$

Therefore, to save natural right doctrines, Strauss must reconsider the premises of philosophy in its "full and original meaning". This is the philosophy which historicism designates as absurd, since its goal—-"to replace opinions about the whole [with] knowledge of the whole" 34 _reduces to a truism due to knowledge resting on mere opinion.

This is why Strauss' solution to the advent of nihilism which is brought about by the rejection of natural right requires him to reexamine the history of natural right doctrines. "If the existence and even the possibility of natural right must remain an open question as long as the issue between historicism and nonhistoricist philosophy is not settled, our most urgent need is to understand that issue." ${ }^{35}$ Yet, in order to achieve this understanding "the problem of historicism must first be considered from the point

\footnotetext{
${ }^{32}$ Ibid. 28.

${ }^{33}$ Ibid. 31 .

${ }^{34}$ Ibid. 30.

${ }^{35}$ Ibid. 33 .
} 
of view of classical philosophy, which is nonhistoricist thought in its pure form." 36 This means that philosophy must be understood as it understood itself. That is to say: "[w]e need... a nonhistoricist understanding of nonhistoricist philosophy."37 This is what Strauss tries to accomplish with his solution to the problem of nihilism and shall be discussed in the following chapter.

\section{Value-Neutrality's Rejection of Natural Right}

For now, it is possible to move onto the second point by which natural right doctrines are rejected. This second rejection takes place when one adopts the view that "there is a variety of unchangeable principles of right or of goodness which conflict with one another, and none of which can be proved to be superior to the others." ${ }^{, 38}$ For Strauss, this position is exemplified by Max Weber. Therefore, it is necessary to briefly examine Weber's position to gain an understanding as to how value-neutrality leads to the rejection of natural right.

Weber's position differs from that of the historicist because the latter "had tried to establish standards that were particular and historical indeed, but still objective." 39 This objectivity stemmed from historicism's insistence that the real is generally accepted and that reality is deemed rational. "Weber rejected the rationality of reality as a dogmatic opinion, [and] he concluded that the only meaning in history is that of the intentions of actors [or individuals]." ${ }^{, 40}$ Yet, this simply makes him seem

\footnotetext{
${ }^{36}$ Ibid.

37 Ibid.

38 Ibid. 36.

${ }^{39}$ Ibid. 37.

${ }^{40}$ Behnegar, Leo Strauss, Max Weber, and the Scientific Study of Politics, 69.
} 
like a radical historicist since they too rejected historicism's claims of rationality and objectivity in history.

Strauss argues, however, that "Weber was... too much impressed by the idea of science to accept historicism without qualification. In fact, one is tempted to suggest that the primary motive of his opposition... was devotion to the idea of empirical science." ${ }^{41}$ What follows from Weber's devotion to science is his distinction between facts and values. This distinction can be understood as "an attempt to separate the objective or transhistorical element of science (findings regarding facts and their causes) from its subjective or historically relative element (the importance and the significance of any findings). ${ }^{, 42}$ Empirical facts, such as the sum of two positive integers equals a larger positive integer, become, for Weber, transhistorical—spanning all of time - and objective - there is no perspective which could correctly claim to the contrary. What effect these facts have, what value they hold, is entirely dependent upon the historical situation in which they are espoused.

For Strauss, this is what separates Weber most definitively from historicism.

[T] he concrete and historical value ideas, of which there is an indefinitely large variety, contain elements of a trans-historical character: the ultimate values are as timeless as the principles of logic. It is the recognition of timeless values that distinguishes Weber's position most significantly from historicism. Not so much historicism as a peculiar notion of timeless values is the basis of his rejection of natural right. ${ }^{43}$

It is these timeless values, then, that Strauss must argue against in order to save natural right from this rejection.

\footnotetext{
${ }^{41}$ Strauss, Natural Right and History, 38.

${ }^{42}$ Behnegar, Leo Strauss, Max Weber, and the Scientific Study of Politics, 70-1.

${ }^{43}$ Strauss, Natural Right and History, 39.
} 
The problem with this goal is that "Weber never explained what he understood by 'values." "44 He had only concerned himself with the relationship of values to facts. For him, "[f]acts and values are absolutely heterogeneous, as is shown directly by the absolute heterogeneity of questions of fact and questions of value. No conclusion can be drawn from any fact as to its valuable character." 45 To ask whether "twice two is four" is a desirable result or a result which one values is to ask an absurdity. In this way, then, it is possible for a social science to make evaluations on social orders but it is impossible for it to make a value judgment. That is to say that "the absolute heterogeneity of facts and values necessitates the ethically neutral character of social science... it is not competent to answer questions of value."46

It is this belief that Strauss shows to lead Weber's thesis to nihilism-to one's inability to view principles as anything other than blind preferences. Yet if one were to separate facts and values in this manner, "[o]nly a comprehensive analysis of social reality as we know it in actual life, and as men always have known it since there have been civil societies, would permit an adequate discussion of the possibility of an evaluat[ive] social science. ${ }^{, 47}$ Even though Weber denied that such a social science is possible, Strauss argues that it is this form of social science that one must defend natural right against - for the alternative is reduced to absurdity.

In order to defend natural right from value-neutrality, then, Strauss first shows that Weber's view of reality as "an infinite and meaningless sequence, or a chaos, of unique and infinitely divisible events, which in themselves are meaningless [and that]

\footnotetext{
${ }^{44}$ Ibid.

${ }^{45}$ Ibid.

${ }^{46}$ Ibid. 40.

${ }^{47}$ Ibid. 78.
} 
all meaning, all articulation, originates in the activity of the knowing or evaluating subject" ${ }^{\prime 48}$ is unattainable. In order to hold this view, one must reject the possibility of a subjective, individual understanding of reality of the world. This negates one of the starting tenets of Weber's thesis and therefore this view of reality must be rejected in order to adequately examine natural right's rejection on the basis of value-neutrality.

It is here, then, that Strauss abandons Weber's thesis for a more consistent value free thesis. For Strauss, it becomes necessary to defend against an analysis of social reality as it is experienced in social life. "Such an analysis would make intelligible the fundamental alternatives which essentially belong to social life and would therewith supply a basis for responsible judgment on whether the conflict between these alternatives is, in principle, susceptible of a solution." ${ }^{49}$ Ultimately, this leads him to the same conclusion that he arrived at in regards to the rejection of natural right on the basis of historicism.

In order to "[g]rasp the natural world as a world that is radically prescientific or prephilosophic, one has to go back behind the first emergence of science and philosophy." ${ }^{, 50}$ That is to say, in order to analyze the social reality of natural right thinkers, one must understand that reality as the natural right thinkers had understood it. In the next chapter, an examination of how Strauss goes about this understanding takes place. It will also show how Strauss finds a solution to nihilism through this analysis.

\footnotetext{
${ }^{48}$ Ibid. 77.

${ }^{49}$ Ibid. 78.

${ }^{50}$ Ibid. 79.
} 
Chapter 3-Strauss' Solution

As explained in Chapter 1, Strauss had a habit of philosophizing in double-

speak, wherein he would present an exoteric argument that any person could grasp and an esoteric argument that would only be known to the true philosopher. What follows is a discussion of the two different solutions that Strauss presents to combat the advent of nihilism.

\section{Exoteric Solution}

"The classic natural right doctrine in its original form, if fully developed, is identical with the doctrine of the best regime." ${ }^{\prime 1}$ An analysis of classic natural right teachings, then, requires that one focus on the arguments for the best regime. "Very roughly speaking, [one] may distinguish three types of classic natural right teachings, or three different manners in which the classics understood natural right. These three types are the Socratic-Platonic, the Aristotelian, and the Thomistic."2

\section{Socratic-Platonic}

Strauss begins his discussion of the Socratic-Platonic teachings with what amounts to a brief summary of Plato's Republic. ${ }^{3}$ The goal of the Republic is to answer the question: "What is justice?" In this regard, it would seem that the SocraticPlatonic teachings on natural right require one to understand what it is to be just. More specifically, natural right in the Socratic-Platonic sense involves determining the just society - the best regime, in other words.

\footnotetext{
${ }^{1}$ Strauss, Natural Right and History, p. 144.

2 Ibid. 146.

${ }^{3}$ Plato, The Republic and Other Works.
} 
As imagined within the Republic, the just society will be composed of two classes - the artisans and the guardians. The guardians will be further divided into the auxiliary and philosophers. ${ }^{4}$ The artisans are the hard laborers, those individuals who produce goods or perform services that are necessary for the functioning of the society. The guardians are those individuals who protect society either through its physical defense as soldiers (the auxiliary) or by means of the rule of law as brought about by philosopher-kings.

Plato continues that if a society is to be perfect, it must be "wise and valiant and temperate and just." $\mathrm{He}$ argues that by defining the first three of these four aspects, one can come to understand what it means for a society to be just. Wisdom is found within the ruling class of philosopher-kings for it is the knowledge "not about any particular thing in the State, but about the whole, and considers how a State can best deal with itself and with other States." ${ }^{\prime 6}$ Courage, unsurprisingly, inhabits the auxiliary class so that they may be victorious in defending the State in physical conflict. Temperance in reference to society expresses "the rule of the better part over the worse."7 It is necessary to maintain harmony amongst the classes. This leaves, as Plato argues, justice, which "is the ultimate cause and condition of the existence of all [virtues], and while remaining in them is also their preservative." ${ }^{\prime 8}$ Simply put, justice within society is the virtue that makes individuals do their own work without trying to

\footnotetext{
${ }^{4}$ Ibid. 53-64.

5 Ibid. 117.

${ }^{6}$ Ibid. 118.

${ }^{7}$ Ibid. 121.

${ }^{8}$ Ibid. 123.
} 
do the work of another. In the just society, an artisan does not try to become a soldier or ruler and vice versa.

Strauss argues that Plato recognizes the philosopher-kings can never rule directly in the actual world and therefore this just society can never be actualized. To counteract this dilemma, Plato develops two mechanisms that will allow the philosophers to rule indirectly — the constitution and the nocturnal council. He brings about the notion of a constitution within the argument of the Statesman. ${ }^{9} \mathrm{He}$ first reiterates the conclusion of the Republic stating that "the ideal is for authority to be invested not in a legal code but in an individual who combines kingship with wisdom." ${ }^{10}$ Yet, as he continues he confesses to the impossibilities of achieving the ideal since "real life countries... don't simply grow a king - an individual whose physical and mental attributes make him stand out from the rest. The only way people can follow the scent of the true political system is apparently by forming assemblies and drawing up written codes." ${ }^{11}$ Here, Plato delineates six possible forms of government by dividing the rule of one, a few, and many into both a legal and illegal form. Respectively, these governments are called constitutional monarchy and despotism, aristocracy and oligarchy, and democracy and 'mob rule'. Of these six reallife governments, Plato designates constitutional monarchy as the best possible. ${ }^{12}$

It would seem, then, that Plato is advocating that a constitutional monarchy is the best regime that can be actualized. It is closer to the truth to say that he is advocating a "mixed" constitution with the presence of the nocturnal council. In the

\footnotetext{
${ }^{9}$ Plato, Statesman.

${ }^{10}$ Ibid. 58.

${ }^{11}$ Ibid. 70.

${ }^{12}$ Ibid. 71-2.
} 
Laws $^{13}$, Plato's goal is to find a median point between the extremes of despotic monarchs - found in the worst of the best forms of governments - and an unbridled, tyrannical mob. "He achieves this by instituting the democratic principle of popular authority in certain aspects of the state, but tempering it in important ways, especially by assigning many of the most important functions to magistrates. ${ }^{\text {14 }}$ Chief among these important functions is the review of the laws, which is performed by "a mixed body of young and old men, who shall be required to meet daily between the hour of dawn and the rising of the sun."15

This is the nocturnal council and it consists of those who have proven their virtue in differing respects. They will be knowledgeable about their laws and the laws that exist elsewhere. In other words, they will possess the kind of knowledge that Plato deemed as wisdom in the Republic and will therefore be philosophers. The nocturnal council, then, becomes the embodiment of the philosopher-kings in the actual world and Plato's best actual regime does not fall so far from his ideal. "[I]f this our divine assembly can only be established, to them we will hand over the [society]... And the state will be perfected and become a waking reality, which a little while ago we attempted to create as a dream."

Strauss argues, then, that in order to combat nihilism, the rule of law must be implemented. Also, the laws by which a society is formed can be changed but must not be done so without great deliberation amongst those most knowledgeable in law in general, who are seen by the society as being virtuous. In this way, nihilism will be

\footnotetext{
${ }^{13}$ Plato, Laws.

${ }^{14}$ Klosko, The Development of Plato's Political Theory, 221.

${ }_{15}^{15}$ Plato, Laws, 280.

${ }^{16}$ Ibid. 297.
} 
staved off by the presence of the laws, for they will be something permanent on which the society can hold. ${ }^{17}$

\section{Aristotelian}

"Plato eventually defines natural right with direct reference to the fact that the only life which is simply just is the life of the philosopher. Aristotle, on the other hand, treats each of the various levels of beings... on its own terms." ${ }^{\prime 18}$ It is Aristotle, then, that begins to bring individualism into the concept of the best regime. Despite this fact, Aristotelian natural right teachings do not stray radically far from that of the Socratic-Platonic teachings.

Aristotle also recognizes six different forms of government divided based on number of rulers and the quality of rule. They are, in fact, the same six that Plato lists in the Statesman. ${ }^{19}$ For him, the difference between a true form of government and a perverse form of government is the interest in which the government serves. "For tyranny is a kind of monarchy which has in view the interest of the monarch only; oligarchy has in view the interest of the wealthy; democracy, of the needy: none of them the common good of all."20

As for the best regime, Aristotle also separates the artisans from the warriors and councilors and recognizes the latter as the true citizens. ${ }^{21}$ Where Aristotle differs from Plato, is in the nature of education. For Plato, education was a tool to manipulate

\footnotetext{
${ }^{17}$ It must be noted that the particular laws are not themselves the tools by which to combat nihilism. Rather it is the presence of law that takes this task.

${ }^{18}$ Strauss, Natural Right and History, 156.

${ }^{19}$ With the exception that Aristotle calls a "democracy" a "constitutional government" and an "mob rule" a "democracy".

${ }^{20}$ Aristotle, Politics, 115.

${ }^{21}$ Ibid. 274-5.
} 
people into the roles they were required to fill within the society. Aristotle, on the other hand, believes that " $[\mathrm{t}]$ he citizen should be moulded to suit the form of government under which he lives."22 It would be necessary, then, for the best regime to use education to mold its citizens to perpetuate itself in the same manner a democracy perpetuates itself through the education of its citizens. In this way, "[s]o long as the corrupting influences of human nature are kept in check through education, the best city can flourish with nothing but ordinary human beings for its guide." 23 The philosopher is no longer a necessary condition for a just society. All citizens are required to be educated in the virtues necessary for the perpetuation of the society and therefore are all equally responsible for the perpetuation of a just society.

In terms of natural right, "[w]hat Aristotle suggests is that the most fully developed form of natural right is that which obtains among fellow-citizens." ${ }^{24}$ It is through their equal "molding" via education that people come to know what is naturally right for their society. Yet at the same time, Aristotle's natural right is not static, it is capable of being changed. ${ }^{25}$ Therefore, the education of the citizens must be continuous and must change with natural right so that they are properly molded for the society in which they live. This being said, natural right should not be changed arbitrarily. Rather, a "true statesman in the Aristotelian sense ... takes his bearings by the normal situation and by what is normally right, and he reluctantly deviates from what is normally right only in order to save the cause of justice and humanity itself." 26

\footnotetext{
22 Ibid. 300.

${ }^{23}$ Kraut, Aristotle: Political Philosophy, 229.

${ }^{24}$ Strauss, Natural Right and History, 157.

25 Ibid.

${ }^{26}$ Ibid. 162, italics added.
} 
Thus, what Strauss wants people to take away from the Aristotelian natural right teachings is that people need both education and conservatism. The former is required to aid people in the perpetuation of the values of the society. The latter assists in preventing people from abandoning their values arbitrarily. Social change, even to save the society itself, must come about reluctantly in order to prevent nihilism from taking hold within the society.

\section{Thomistic}

For Strauss, the Thomistic natural right teachings serve little purpose, other than being a direct cause for modern natural right thought. This is in spite of the fact that Thomas Aquinas holds many of the views that the Socratic-Platonic and Aristotelian teachings put forward. Like Aristotle, he accounts for the differences in laws among societies by claiming that the "general principles of the natural law cannot be applied to all men in the same way, on account of the great variety of human affairs." 27 This is also evidence of the influence of Plato's teachings, since man's relationship to the natural law is dependent upon their affairs - as in the separation of classes within the Republic. Aquinas also speaks of inclinations towards specific ends, ${ }^{28}$ a teleological view very similar to that of Aristotle.

Even his definition of the natural law falls in line with the previous thinkers. "Things may be said to pertain to the natural law for two reasons. First, if there is a natural inclination to them... Secondly, if nature does not lead us to do what is

\footnotetext{
${ }^{27}$ Aquinas, The Political Ideas of St. Thomas Aquinas, 59.

${ }^{28}$ Aquinas, Selected Political Writings, 123.
} 
contrary." 29 What, then, is present in the Thomistic teachings that causes Strauss to dismiss them so readily? This is due to the fact that "the Thomistic view of natural law is that natural law is practically inseparable not only from natural theology... but even from revealed theology.",30

This merging of theology and law is not enough for Strauss to reject the Thomistic teachings outright. It is the consequences that stem from this combination that causes problems for Strauss - in particular the rejection of theology. For him, this is the first step towards nihilism because "[m] odern natural law was partly a reaction to this absorption of natural law by theology." 31 That is to say, classic natural right teachings were rejected by the modern natural right thinkers because the latter rejected the teachings of theology. It was necessary, then, for these modern natural thinkers to reformulate natural right in such a way as to move it away from the Thomistic teachings - that is to say, the modern thinkers sought to separate the doctrine of natural right from theological authority in order to invigorate philosophy.

\section{Strauss' Exoteric Solution}

It is now possible to see what it is that Strauss has in mind as his exoteric solution to nihilism. By arguing that the natural right teachings need to be promoted, he has been reinforcing the views of his American audience. Many of the views he is putting forward are those that are part of the American ideology and are put forward in the writings of the "Founding Fathers".

\footnotetext{
${ }^{29}$ Ibid. 127.

${ }^{30}$ Strauss, Natural Right and History, 164.

${ }^{31}$ Ibid.
} 
The rule of law and deliberation in making changes found in the SocraticPlatonic teachings can be equated to America's Constitution and the long process of deliberation required in making changes to it. The need for education and conservatism in the Aristotelian teachings are present in the existence of public education and again in the difficulties present in making changes to the Constitution. Finally, keeping political philosophy separate from theology, which Aquinas failed to do and therefore created the conditions for the first steps towards nihilism, is similar to the separation of church and state within the first amendment to the Constitution.

This conclusion is not entirely unsurprising considering the fact that he started the book by quoting a passage from the Declaration of Independence. ${ }^{32}$ It is the ideals of America that are still held by Americans that has kept it from devolving into a nihilistic land similar to Nazi Germany_-where one not only turns a blind eye to acts he would otherwise deem deplorable but accepts such acts as being merely different in principle. It will be this continued holding of those beliefs that will allow America to weather the advent of nihilism.

\section{Esoteric Solution}

To understand what Strauss is truly arguing between the lines, one must read him with a critical eye and a "philosophical" mind. Yet, to do so does not clarify Strauss' ultimate argument. This is not the first attempt to clarify that argument. Some, such as Shadia Drury ${ }^{33}$ and Peter Levine, ${ }^{34}$ read him as the esoteric writer I claim him

\footnotetext{
${ }^{32}$ Ibid. 1.

${ }^{33}$ Drury, "The Esoteric Philosophy of Leo Strauss", 315-337.

${ }^{34}$ Levine, Nietzsche and the Modern Crisis of the Humanities, 159-67.
} 
to be; while others, such as the Zuckerts, ${ }^{35}$ claim that there is no esoteric meaning to his writings at all. ${ }^{36}$ Rather, these latter writers claim that "Strauss writes with 'pedagogical reserve",37 and in so doing "fails to say all that he thinks, or, better put perhaps, he fails to flesh out... the full scope of his reasoning."38

The first order of business, then, is to determine whether Straus is writing with pedagogical reserve or esoterically. As the title of this section implies, the author believes that Strauss is, in fact, arguing in an esoteric manner. To prove this point, an examination of what writers like the Zuckerts believe to be the difference between the practices of esotericism and pedagogical reserve is necessary. For them, "[e]soteric writers... give the impression that they agree with the religious orthodoxies of their day." 39 This Strauss does by beginning Natural Right and History by quoting the Declaration of Independence and citing the positive impact that the holding of the beliefs therein has had on America as a nation. ${ }^{40}$ The arguments he makes in the book, as shown above, lead one to believe that he is advocating the social religion of America. The question now becomes whether there is present within the work another "true" understanding which "involves bringing out the esoteric doctrine, which stands at a distance from the dominant impression left by the surface of [the] texts.",41

\footnotetext{
${ }^{35}$ Zuckert, The Truth about Leo Strauss, 136-54.

${ }^{36}$ Such a claim, however, must not be taken without a grain of salt. The Zuckerts are, in fact, Straussian and it is entirely possible that they adopted the esoteric writing style they argue against presently. I will use their position, therefore, as a means to show that Strauss writes in an esoteric manner but will not deny that some thinkers, if not the Zuckerts, may argue against such a proposition in a manner similar to that being proposed by the Zuckerts.

${ }^{37}$ Zuckert, The Truth About Leo Strauss, 136.

${ }^{38}$ Ibid.

${ }^{39}$ Ibid.

${ }^{40}$ Strauss, Natural Right and History, 1.

${ }^{41}$ Zuckert, The Truth About Leo Strauss, 136.
} 
There must be evidence, then, that shows that Strauss does not truly intend to argue for the equality of all men or the existence of inalienable rights. In other words, if Strauss is truly an esoteric writer, it must be possible to show that he rejects the existence of inalienable rights given to men and the equality of men. What follows is the search for Strauss' esoteric arguments.

\section{Strauss' Rejection of Rights}

To understand Strauss' rejection of the rights of man, one must first see the link that he paints between Thomas Hobbes, the "founder" of modern political philosophy, and John Locke, the most influential philosopher on American idealogy. The link between these two thinkers is enough for Strauss to demarcate the modern notion of rights as a "rejection of natural right... bound to lead to disastrous consequences." 42

Looking at Hobbes, Strauss finds that there is one major break with classical political philosophy. Where the classics "assumed that man is by nature a political or social animal... [Hobbes] accepts [the] view that man is by nature or originally an apolitical and even an a-social animal." "It is from this understanding of "natural" man that Hobbes brings about his argument for the structure of political order. By reversing the outlook on the nature of man, Hobbes also reverses the course of political philosophy. The goal of political philosophy can no longer be to perfect man's nature, since to do so would eliminate political order. Rather, political philosophy must use man's nature to form practical conceptions necessary for man to live together.

\footnotetext{
${ }^{42}$ Strauss, Natural Right and History, 3.

${ }^{43}$ Ibid. 169.
} 
In this way, Hobbes attempts to deduce natural law "from how men actually live, from the most powerful force that actually determines all men" ${ }^{44}$ in order to give it the practical value he deems necessary. What he determines is that the most powerful force that acts on man is the same as the most powerful passion — "the fear of death and, more particularly, the fear of violent death at the hands of others." ${ }^{, 45}$ Put more simply, natural law will have practical value if it is deduced from man's desire for self-preservation. According to Strauss, Hobbes believes that "the desire for selfpreservation is the sole root of all justice and morality, the fundamental moral fact is not a duty but a right; all duties are derivative from the fundamental and inalienable right of self-preservation. ${ }^{46}$

From this conception of natural law, Hobbes determines that civil society can no longer be organized towards the promotion of the virtuous life. Rather, its only responsibility is towards protecting the natural right to life of each individual. It is not difficult, then, to see the influence of Hobbes' conception of political philosophy in the Declaration of Independence. Yet, “[w] hat the bold Hobbes began, the 'cautious' Locke completed."

This seems to be outright incorrect at first glance, a fact which Strauss himself admits freely:

Locke seems to reject altogether Hobbes's notion of natural law and to follow the traditional teaching. He certainly speaks of man's natural rights as if they were derivative from the law of nature, and he accordingly speaks of the law of nature as if it were a law in the strict sense of the term. ${ }^{48}$

\footnotetext{
${ }^{44}$ Ibid. 180.

${ }^{45}$ Ibid.

${ }^{46}$ Ibid. 181, italics added.

${ }^{47}$ McAlister, Revolt Against Modernity, 157.

${ }^{48}$ Strauss, Natural Right and History, 202.
} 
This is due in no small part to Locke's reliance on the works of Richard Hooker to establish his philosophy in the popular opinion of his time. "Locke wasted no opportunity to point to his agreement with Hooker (an undeniable defender of the faith) while remaining silent, with one exception, concerning their differences."

Despite these affirmations of orthodoxy, Strauss concludes "that Locke cannot have recognized any law of nature in the proper sense of the term." ${ }^{, 50}$ Rather, much “[1]ike Hobbes, Locke found no natural law but rather universal human characteristics that establish natural rights but not duties." ${ }^{, 51}$ Yet, where Hobbes limited his teaching to a single right, Locke found three such rights. Locke's rights are established by readopting the social nature of man that Hobbes had rejected. "If the state of nature were characterized by habitual conflict between self-preservation and the preservation of others, [then, Locke argues that] the law of nature would be ineffectual... the state of nature must be a social state." 52 This social state still holds self-preservation as a right but one tempered by Locke's two other rights.

The first of these two rights is the pursuit of happiness - a passion that is universally effective in man, much like Hobbes envisioned the passion to selfpreservation. This pursuit of happiness is representative of Locke's notion of libertythat man should be free from restriction to pursue their means of happiness. The second is the right to property, which is necessitated by the right to self-preservation. "If everyone has the natural right to preserve himself, he necessarily has the right to

\footnotetext{
${ }^{49}$ McAlister, Revolt Against Modernity, 158.

${ }_{51}^{50}$ Strauss, Natural Right and History, 220.

${ }_{51}^{51}$ McAlister, Revolt Against Modernity, 158-9.

${ }^{52}$ Strauss, Natural Right and History, 224.
} 
everything that is necessary for his self-preservation." ${ }^{, 53}$ Thus, Locke establishes two rights listed in the Declaration of Independence—-life, or self-preservation, and liberty, or the pursuit of happiness. He also established the right to property, which the American founders construed into the ability to freely obtain property without the constraints of the British Empire.

What have been established, then, are the philosophical roots of the inalienable rights proclaimed in the Declaration. How Strauss rejects these rights has not been made readily apparent as of yet. However, all the points have been made, it is just necessary to connect them in order to see the whole picture.

The natural rights of Hobbes and Locke stem from the rejection of the classical teachings on natural right. Society is no longer concerned with the virtuous perfection of man; rather, its goal is simply to safeguard the rights of individuals. It is this shift from the good of the society to the good of the individual that leads man to be "effectively emancipated from the bonds of nature, and therewith the individual is emancipated from those social bonds which antedate all consent. ${ }^{, 54}$ In other words, the rejection of classic natural right teaching by Hobbes and Locke free the individual to reject tradition. Without the bonds of nature or tradition, one is required to rely on his blind preferences. This leads to the crisis of modernity. "If our principles have no other support than our blind preferences, everything a man is willing to dare will be

\footnotetext{
${ }^{53}$ Ibid. 235.

${ }^{54}$ Ibid. 248.
} 
permissible. ${ }^{„ 55}$ This predicament cultivates nihilism. Therefore, it is necessary to reject a doctrine of rights to preserve society.

\section{Strauss' Rejection of the Equality of Man}

How Strauss rejects the notion of equality is a more complicated matter than his rejection of rights. The first step is to recall his ultimate goal in the work, both in his exoteric and esoteric arguments—a return to classic natural right teachings. There is recognition in all three ${ }^{56}$ natural right teachings of the difference in men. This alone, however, is not enough to say that Strauss outright rejects the equality of man since it is fair to say that one could still believe in the equal value of all individuals despite the inherit differences among them.

Yet, Strauss argues that the classics did not even hold this doctrine of equal treatment.

Since the classics viewed moral and political matters in the light of man's perfection, they were not egalitarians. Not all men are equally equipped by nature for progress toward perfection, or not all "natures" are "good natures." While all men, i.e., all normal men, have the capacity for virtue, some need guidance by others, whereas others do not at all or to a much lesser degree... Since men are then unequal in regard to human perfection, i.e., in the decisive respect, equal rights for all appeared to the classics as most unjust. ${ }^{57}$

Therefore, a return to classic natural right teachings must lead to a rejection of the doctrine of equality. Yet it could still be said that Strauss could readopt the pursuit of virtue without abandoning the modern doctrine of equality. How can one be sure he rejects equality by simply wanting to return to the classical teachings? A further look

\footnotetext{
${ }^{55}$ Ibid. 4-5.

${ }^{56}$ Socratic-Platonic, Aristotelian, and Thomistic

${ }^{57}$ Strauss, Natural Right and History, 134-5.
} 
into his works show that he distinguishes people based on their capacity towards wisdom, or the classic virtue necessary for human perfection.

For Strauss there are several "classes" of people with regard to wisdom. In order of the smallest capacity for wisdom to the largest these classes are: the masses, the intellectuals, the sophists, the gentlemen, and the philosophers. Strauss understands philosophers as those individuals capable of living philosophically. That is to say, he saw "[p]hilosophy [a]s a way of life rather than a set of beliefs or even a deeply reflective attitude toward the fundamental issues. Philosophers form a distinct class... driven by a passionate desire to have what is missing. ${ }^{, 58}$ Yet, many are driven by a desire for what they feel is missing. The difference between them and a philosopher is the object of desire. While most go out "in search of power or other vulgar pursuits... for the philosopher, knowledge is the object of satisfactionknowledge of the "whole.",59 In other words, Strauss views the philosopher in the same light as the classical teachings to which he wishes to return, especially that of Plato.

Moving down the list, "[t]he gentleman is not identical with the [philosopher]. He is the political reflection, or imitation of the [philosopher]." ${ }^{\prime 60}$ The gentleman is the modern equivalent of an aristocracy. "[T] hey have a noble contempt for precision, because they refuse to take cognizance of certain aspects of life, and because, in order

\footnotetext{
${ }^{58}$ McAlister, Revolt Against Modernity, 208.

${ }^{59}$ Ibid.

${ }^{60}$ Strauss, Natural Right and History, 142.
} 
to live as gentlemen, they must be well off." ${ }^{, 61}$ In short, they are the modern "political class"-knowledgeable in many respects but only insofar as they deem it useful.

The sophist also possesses knowledge but "is unconcerned with the truth, or does not love wisdom... He is concerned with wisdom, not for its own sake... but for the sake of the honor or the prestige that attends wisdom." ${ }^{32}$ The sophist is the celebrity "expert" - one who uses his knowledge to gain wealth and fame. He may be aware of the truth but is only concerned with how that awareness could benefit him.

The difference between an intellectual and a philosopher is the same as "the difference between gentlemen and philosophers, on the one hand, and the difference between sophists... and philosophers, on the other." ${ }^{, 63}$ The intellectual is a combination of the sophist and the gentleman. He has knowledge in a particular field but has no regard for the "whole". He uses this knowledge to achieve some goal, noble or otherwise, in an attempt to achieve honor. He may be the scientist working to improve some aspect of daily life without regard to how such an "improvement" will impact the overall human condition. "Such beings are by no means the worst human beings, but they are the root of our trouble in the sense that the movement that led to their emergence is also the movement that is responsible for the contemporary [crisis]. ${ }^{, 64}$

No, the intellectual is not the worst class of human beings. For Strauss, that distinction is left for the masses. The masses are the reason behind the need for esoteric teachings. "[T]he influence of [their] persecution on literature is precisely that

\footnotetext{
${ }^{61}$ Ibid.

${ }^{62}$ Ibid. 116.

${ }^{63}$ Ibid. 34.

${ }^{64}$ Behnegar, Leo Strauss, Max Weber, and the Scientific Study of Politics, 106.
} 
it compels all writers who hold heterodox views to develop a peculiar technique of writing... between the lines." 65 Yet, it is not just the persecution of the masses that lead a writer to write esoterically. Esoteric writing is necessary to hide the truth from the masses - a truth that allows for "everything a man is willing to dare [to] be permissible."

In this way, Strauss shows his agreement with the classic teachings of natural right. He uses the esoteric style to show he rejects the doctrine of rights, which in turn shows he deems it necessary to treat people unequally with regard to human perfection. Thus, Strauss rejects the doctrine of equality with the same stroke by which he rejects the doctrine of rights.

\section{Strauss' Esoteric Solution}

Much in the same way as Locke hid behind the popular views of Hooker to reject Hooker's philosophy, so too has Strauss used the popular views of the American people to reject the core ideology of the United States. Yet, he found it necessary to prop up the ideology exoterically. Why? The answer lies in the esoteric solution to the advent of nihilism — a return to the classic teachings of natural right. "Nothing, says Strauss, separates the ancients from the moderns more than the attitude they have towards 'noble (or just) lies' and 'pious frauds'." ${ }^{67}$ It is necessary, according to Strauss, to give the masses a noble lie to prevent the breakdown of society.

\section{Strauss: Closet Nihilist?}

\footnotetext{
${ }^{65}$ Strauss, Persecution and the Art of Writing, 24.

${ }^{66}$ Strauss, Natural Right and History, 4.

${ }^{67}$ Drury, "The Esoteric Philosophy of Leo Strauss", 332.
} 
The question becomes what does Strauss view to be the truth that needs to be hidden by the "noble lie" of natural right? He claims early on that "[t]he contemporary rejection of natural right leads to nihilism—nay, it is identical with nihilism." 68 If Strauss uses natural right as the "noble lie", then it is safe to assume that he rejects it as philosophical truth. His rejection of natural right is, as he put it, identical with nihilism.

Yet, what does Strauss' nihilism look like? An examination of the text paints a bleak picture. Within his form of nihilism "our ultimate principles have no other support than our arbitrary and hence blind preferences" which leads to their abandonment and "everything a man is willing to dare" becomes permissible. It is a view "that every preference, however evil, base, or insane, has to be judged before the tribunal of reason to be as legitimate as any other preference." ${ }^{69}$ In other words, the adoption of Straussian nihilism leads to chaos.

The reason behind Strauss' argument against nihilism is not that he rejects nihilism but that he fears the consequences of the masses adopting his nihilistic viewpoint. This can best be seen in the following, where in true esoteric fashion Strauss adopts a stance that places him with the masses:

In order to live, we have to silence the easily silenced voice of reason, which tells us that our principles are in themselves as good or as bad as any other principle. The more we cultivate reason, the more we cultivate nihilism: the less are we able to be loyal members of society. ${ }^{70}$

\footnotetext{
${ }^{68}$ Strauss, Natural Right and History, 5.

${ }^{69}$ Ibid. p. 42.

${ }^{70}$ Ibid. 6.
} 
The "truth" of nihilism, for Strauss, must remain hidden from the masses in order to preserve society. 
Chapter 4 - Friedrich Nietzsche

Now that Strauss has been identified as a nihilist thinker, it must be stated that his version of nihilism differs from that of the two nihilist thinker previously mentioned—Friedrich Nietzsche and Michel Foucault. This and the following chapter shall be concerned with establishing how exactly Straussian nihilism differs from both Nietzschean and Foucauldian nihilism. To begin, this chapter shall examine the work of Nietzsche and then contrast his nihilism with that of Strauss. The following chapter shall perform the same task with Foucault.

\section{Nietzschean Nihilism}

As mentioned in the introductory chapter, Nietzschean nihilism stems from Nietzsche's existentialist investigations. More specifically, it develops out of his perspectivist analysis of human history and culture. Therefore, to understand the development of Nietzschean nihilism one must first understand the notion of perspectivism.

\section{Perspectivism}

As stated before, perspectivism is 'the view that 'truths' are one and all interpretations formulated from particular perspectives." ${ }^{\text {Th }}$ This is similar to what Strauss referred to as radical historicism. It is the rejection of the theoretical viewpoint. "There is no perspective-free, global viewpoint, no 'God's eye' view, only this or that perspective." ${ }^{, 2}$ While this defines the notion of perspectivism, it does not explain what Nietzsche meant to accomplish by using it as an analytical tool. It has

\footnotetext{
${ }^{1}$ Magnus and Higgins, "Nietzsche's works and their themes", 31-2.

${ }^{2}$ Solomon, "Nietzsche ad hominem: Prespectivism, personality and ressentiment", 180.
} 
become necessary, then, to look more closely at how Nietzsche uses perspectivism to truly understand its impact on his thought.

As mentioned in chapter one, there are two primary interpretations of Nietzsche's perspectivism. The first views it as a form of neo-Kantianism. The other, much like Strauss, sees it as a form of radical relativism. The goal, then, is to resolve this debate with an examination of Nietzsche's use of perspectivism. But first, one must understand what it means to claim that Nietzsche's perspectivism is a form of neo-Kantianism.

Briefly speaking, Kant, with regards to truth, saw the world as being separated "into a world of the senses and a world of the understanding."3 The former he designated as the phenomenal world and the latter as the noumenal world. The first is how the world seems to one's senses - it is the empirical world. The other is how the world is in itself.

Nietzsche's perspectivism, then, is a form of neo-Kantianism if he holds that such a dualism exists. If, however, perspectivism is a form of radical relativism, then there can exist "no external comparison or correspondence... between what we believe and truth 'in itself' but only the comparison, competition, and differences in quality within and between the perspectives themselves." ${ }^{4}$ That is to say, perspectivism is a form of relativism if it does not recognize a truth separate from what individuals believe.

\footnotetext{
${ }^{3}$ Kant, Critique of Pure Reason, 266.

${ }^{4}$ Solomon, "Nietzsche ad hominem: Prespectivism, personality and ressentiment", 180.
} 
Nietzsche's position is made clear when one looks at the first chapter in Human, All Too Human. ${ }^{5}$ It is a work wherein Nietzsche has as a goal the development of "a chemistry of moral, religious, aesthetic ideas and feelings, a chemistry of all those impulses that we ourselves experience in the great and small interactions of culture and society." ${ }^{6}$ It is also the first published work where Nietzsche utilizes perspectivism.

In the work it is pretty clear that Nietzsche rejects the notion of a dualist world in favor of a conception of the world only as individuals know it. He claims early in the first chapter that "there are no eternal facts, nor are there any absolute truths." ${ }^{, 7}$ In this way, he denies "truth in itself". However, one cannot claim that he outright denies the possibility of "truth in itself". In fact, Nietzsche states that the possibility exists"there might be a metaphysical world; one can hardly dispute the absolute possibility of it." $" 8$

Yet in the same aphorism in which he defends the possibility of a world-initself, Nietzsche makes clear that even if there were knowledge of a metaphysical world it would be of little consequence.

This [possibility] is a purely scientific problem, and not very suited to cause men worry. But all that has produced metaphysical assumptions and made them valuable, horrible, pleasurable to men thus far is passion, error, and selfdeception. The very worst methods of knowledge, not the very best, have taught us to believe in them. When one has disclosed these methods to be the foundation of all existing religions and metaphysical systems, one has refuted them... For there is nothing at all we could state about the metaphysical world except its differentness, a differentness inaccessible and incomprehensible to us... No matter how well proven the existence of such a world might be, it

\footnotetext{
${ }^{5}$ Nietzsche, Human, All Too Human, 13-38.

${ }^{6}$ Ibid. 14.

${ }^{7}$ Ibid. 15 .

${ }^{8}$ Ibid. 17.
} 
would still hold true that the knowledge of it would be the most inconsequential of all knowledge. ${ }^{9}$

So while Nietzsche does not deny that it may be possible that a world-in-itself exists and that it may be possible that one could have knowledge of such a world, he still holds that even if it were so, it would not matter. The world-in-itself would be far too alien for one to comprehend and, therefore, would provide no real knowledge of itself other than how alien it is.

It is reasonable, then, to side with those who claim that Nietzsche's perspectivism is a form of radical relativism, one where the only knowledge an individual has is that which he attains through his own perspective, there is no truth outside of this perspective. In this way, all eternal truths must be rejected-or in Straussian language, all the principles of civilization must be rejected. What remains is the knowledge that one will find useful for life: that which he developed through his own perspective.

\section{Zarathustra and His Teachings}

The core of Nietzschean nihilism is found in the work Thus Spoke Zarathustra. ${ }^{10}$ This core consists of the three main teachings of the prophet, Zarathustra - that of the Übermensch, the will to power, and eternal recurrence. The goal of this section is to examine each of these teachings in turn to discover their role in Nietzschean nihilism.

\footnotetext{
${ }^{9}$ Ibid. 17-8.

${ }^{10}$ Nietzsche, Thus Spoke Zarathustra.
} 
$\ddot{U}$ bermensch. While the concept of the Übermensch ${ }^{11}$ is discussed little in Thus Spoke Zarathustra, it still serves a central function, especially in regards to the other two central teachings. It is, in fact, the driving force behind the two other teachings for one cannot fully understand them without first understanding the Übermensch. There are several tenets to the Übermensch, each of which aid in the understanding of what Nietzsche is trying to accomplish in his philosophy.

Yet to grasp this understanding, a different approach will be necessary due to the very different nature of Thus Spoke Zarathustra. The work is the equivalent of Nietzsche's gospel. As such, it is written in a narrative form that parodies that of the books of Matthew, Mark, Luke, and John from the Christian Bible. Zarathustra, the mouthpiece for Nietzsche, becomes the prophet of a new "religion" — the religion of the Übermensch. The easiest way to understand the meaning behind the literary prose is to dissect it. In this regard, the text shall first be quoted, and then a discussion of its meaning shall follow.

"I teach you the overman. Human being is something that must be overcome." ${ }^{\prime 2}$ The Übermensch for Nietzsche is the "next level" of humanity, much like humanity can be viewed as the next level of ape. Unlike the transition from ape to man, however, Nietzsche does not believe that this will be a natural transition brought about through the process of evolution. Rather, he believes that the Übemensch is an

\footnotetext{
${ }^{11}$ This term is often translated as overman or superman and as such these terms will be used intermittently as one in the same throughout this section, usually when quoting another source. For a discussion as to why it is best to use the German term rather than adopt either of the translations, see Danto, Nietzsche as Philosopher, 178-9.

${ }^{12}$ Nietzsche, Thus Spoke Zarathustra, 5.
} 
individual capable of overcoming the faults of humanity to become more than human, similar to the Platonic notion of a philosopher. ${ }^{13}$

"The overman is the meaning of the earth. Let your will say: the overman shall be the meaning of the earth! I beseech you, my brothers, remain faithful to the earth and do not believe those who speak to you of extraterrestrial hopes!"14 It is the Übermensch, according to Nietzsche, that will reject the notion of a metaphysical world in favor of focusing on the world as perceived by man. He rejects the notion of the soul in favor of the promotion of the body. "[T]he body is the ground of all meaning and knowledge, and... health and strength should be recognized and sought as virtues."

"Mankind is a rope fastened between animal and overman - a rope over an abyss... What is great about human beings is that they are a bridge and not a purpose: what is lovable about human beings is that they are a crossing over and a going under." ${ }^{\prime 6}$ Humanity, for Nietzsche, is merely a stage — something that will eventually be superseded by the Übermensch. "We go beyond ourselves by overcoming something in ourselves, and it is that which goes under." 17 The Übermensch, then, is a goal attainable by human beings if they are capable of overcoming some part of themselves.

To approach this in another fashion, one can gain an understanding of what one needs to overcome on the path to the Übermensch if one understands its

\footnotetext{
${ }^{13}$ But only in concept, for the Übermensch will reject the idea of "truth" that the Platonic philosopher seeks.

${ }^{14}$ Nietzsche, Thus Spoke Zarathustra, 6.

${ }_{15}^{15}$ Magnus and Higgins, "Nietzsche's works and their themes", 41.

${ }^{16}$ Nietzsche, Thus Spoke Zarathustra, 7.

${ }^{17}$ Danto, Nietzsche as Philosopher, 180.
} 
antithesis - the last man. The last man is "the human type whose sole desire is personal comfort, happiness." ${ }^{\prime 18} \mathrm{He}$ is the man who no longer attempts to create anything beyond himself - even, as Nietzsche will argue, to the point of not having the desire to have children.

"[T]he earth has become small, and on it hops the last human being, who makes everything small. His kind is ineradicable... the last human being lives longest." ${ }^{\prime 19}$ The last man thinks only of his own self. His worldview, then, is small and relates only to his personal benefit. Nietzsche realizes that such people will always exist and due to their selfish nature will preserve themselves the longest.

"We invented happiness' say the last human beings, blinking." 20 The last man is happy with just being happy to the point that he will invent his own happiness. The last man is content to accept the world as it is and remain complacent. The blinking, which Nietzsche mentions every time that the last man speaks, could represent one of three things. Either the last man's willingness and ability to lie to himself, his inability to see the world clearly, or his insipidness - comparing him to a herd animal such as a sheep or cow through allegory.

The Übermensch, then, can be defined as a goal of man that strives to separate himself from the "herd" of the last man. He is the individual who overcomes his humanity to become something more than human. One who recognizes the uselessness of denying the body but is not afraid of being unhappy in the pursuit of creating meaning for himself.

\footnotetext{
${ }^{18}$ Magnus and Higgins, "Nietzsche's works and their themes", 40.

${ }^{19}$ Nietzsche, Thus Spoke Zarathustra, 10.

${ }^{20}$ Ibid.
} 
Will to Power. For Nietzsche, the will plays a central role for humanity. It is the "voice" of the body — that urging to act. It is not simply the urge to live. In fact, Nietzsche argues that such a will, a will to existence, does not exist. "For, what is not can not will; but what is in existence, how could this still will to exist! Only where life is, is there also will; but not will to life, instead... will to power!"21

The means by which a man can become an Übermensch is this will to power. The will to power is the means by which humans can overcome and thus become Übermenschen. The will to power can take many forms but it always strives for the betterment of humanity. It is the reason behind the values of society. "A tablet of the good hangs over every people. Observe, it is the tablet of their overcomings; observe, it is the voice of their will to power.",22

But for the will to power to aid an individual onto the path to the Übermensch, that individual must recognize these "tablets of the good" as creations of man. "Indeed, humans gave themselves all of their good and evil. Indeed, they did not take it, they did not find it, it did not fall to them as a voice from heaven." ${ }^{, 23}$ For once one recognizes this, he can use the will to power to aim for a singular goal— the Übermensch. "A thousand goals there have been until now, for there have been a thousand peoples. Only the fetters for the thousand necks are still missing, the one goal is missing. Humanity still has no goal.",24

That goal, Nietzsche suggests is valuing life in itself rather than the ideals set upon a people by their teachings of "good" and "evil". "Much is esteemed more highly

${ }^{21}$ Ibid. 90.

${ }^{22}$ Ibid. 42.

${ }^{23}$ Ibid. 43.

${ }^{24}$ Ibid. 44. 
by life than life itself; yet out of esteeming itself speaks - the will to power!"25 The will to power, then, can lead one to the Übermensch by having one reject the metaphysical nature of social values and adopt values that "esteem" life itself.

Eternal Recurrence. The idea of eternal recurrence, which Nietzsche claimed was the central thought of Zarathustra, ${ }^{26}$ was first proposed by Nietzsche as a thought experiment in The Gay Science. ${ }^{27}$ There, he borrows language from Descartes to espouse the conception of eternal recurrence to have existential import. The thought experiment proceeds as follows:

What if some day or night a demon were to steal into your loneliest loneliness and say to you: 'This life as you now live it and have lived it you will have to live once again and innumerable times again; and there will be nothing new in it, but every pain and every joy and every thought and sigh and everything unspeakably small or great in your life must return to you, all in the same succession and sequence... Would you not throw yourself down and gnash your teeth and curse the demon who spoke thus? Or have you once experienced a tremendous moment when you would have answered him: 'You are a god, and never have I heard anything more divine. ${ }^{28}$

In this formulation, the idea of eternal recurrence "is important primarily because it indicates a desirable attitude towards life. If one can genuinely affirm eternal recurrence, one considers one's life intrinsically valuable, worth living over and over again. $" 29$

Yet, much scholarly conflict takes place over the meaning of eternal recurrence. This is mostly due to comments and notes made by Nietzsche outside his published works but there are those who argue that Nietzsche is providing "scientific"

\footnotetext{
${ }^{25}$ Ibid. 90.

${ }^{26}$ Nietzsche, The Anti-Christ, Ecce Homo, Twilight of the Idols, and Other Writings, 123.

${ }^{27}$ Nietzsche, The Gay Science.

${ }^{28}$ Ibid. 194.

${ }^{29}$ Magnus and Higgins, "Nietzsche's works and their themes", 37.
} 
rather than "existential" theory. ${ }^{30}$ Such an argument, however, seems out of character for Nietzsche. He has set out to make this life worth living by denying the "truth" of metaphysical claims. By using the notion of eternal recurrence only as a thought experiment, that emphasis is enhanced; while using it as a theory to explain the operations of the universe diminishes the importance of one's life. Therefore, it is prudent to view the idea of eternal recurrence as it is laid out in The Gay Science-as no more than a thought experiment to affirm the value of one's life. By doing so, one recognizes that Nietzsche wishes to put the focus on the world as it is experienced by the individual rather than some world-in-itself or world-to-come.

Turning back to Zarathustra, the doctrine of eternal recurrence stems from a vision wherein he argues with “'the spirit of gravity,' who urges him to see time as a kind of straitjacket that sentences [one] in the future to consequences determined by the past. ${ }^{, 31}$ In other words, the spirit seeks to maintain a description of time that leaves man powerless. Zarathustra counters the spirit's claim with the doctrine of eternal recurrence, "which gives primacy to the present moment as the moment in which one lives and is free to express oneself." ${ }^{\text {" }} 2$ It is an interpretation of time that restores focus on the experiential world.

Summation of Zarathustra's Teachings. These three teachings- the Übermensch, the will to power, and eternal recurrence — make up the bulk of what Nietzsche believes nihilism can develop. The Übermensch is that individual who is capable of overcoming his herd mentality — that which defines the last man — and creating for

\footnotetext{
${ }^{30}$ For such an argument see Danto, Nietzsche as Philosopher, 184-95.

${ }^{31}$ Higgins, Nietzsche's Zarathustra, 151.

${ }^{32}$ Ibid. 152. Italics added.
} 
himself his own meaning for life. Achieving this meaning is done through the will to power which motivates this individual to create something beyond himself. It is eternal recurrence, however, that serves as the inspiration to break away from the herd and strive to become the Übermensch by having one call into question the choices that he makes. By having one ask if they would be happy reliving one's life exactly as it has been lived, Nietzsche believes that the Übermensch would reject the choices expected of him by the herd and seek his own "path".

Yet Nietzsche does not believe that the path to the Übermensch is achievable by just anybody. For him, there are many individuals—-the rabble—on which his message will be lost. "You higher men, learn this from me: in the market place no one believes in higher men... But the rabble blinks 'we are all equal... there are no higher men, we are all equal, human is human, before God - we are all equal!' ... But we do not want to be equal before the rabble. ${ }^{33}$ His discussion of this inequality and what it means for his nihilism is found in his genealogy, which shall be discussed next.

\section{Nietzsche's Genealogy}

Nietzsche's genealogical discussion focuses on the origins of the tenets of modern morality. His goal is to undermine the popular conception that they are "given" and unchangeable by revealing their human construction. ${ }^{34} \mathrm{He}$ accomplishes this in three essays that comprise his work, On the Genealogy of Morality. ${ }^{35}$ These

\footnotetext{
${ }^{33}$ Nietzsche, Thus Spoke Zarathustra, 232.

${ }^{34}$ Magnus and Higgins, "Nietzsche's works and their themes", 52.

${ }^{35}$ Nietzsche, On the Genealogy of Morality.
} 
three essays "offer accounts of the origins of our conceptions of the 'good,' the experience of bad conscience, and practices of asceticism." ${ }^{\text {36 }}$

The first essay is a critique of the Christian origins of modern morality. He begins by claiming that the origin of good does not stem from what people found useful. Rather, he claims:

the judgment 'good' does not emanate from those to whom goodness is shown! Instead it has been 'the good' themselves, meaning the noble, the mighty, the high-placed and the high-minded, who saw and judged themselves and their actions as good, I mean first-rate, in contrast to everything lowly, low-minded, common and plebian. ${ }^{37}$

His argument, then, is that the conception of "good" originally stems from the aristocratic view of the self. "Bad," in this conception, is the aristocratic view of the other - the poor, the ignoble, the common man.

Yet, modern morality holds that the good is that which helps men equallymodern morality makes all men common. This reversal, Nietzsche accredits to the rise of Judeo-Christian ideals.

Nothing which has been done on earth against 'the noble'... is worth mentioning compared with what the Jews have done against them: the Jews, that priestly people, which in the last resort was able to gain satisfaction from its enemies and conquerors only through a radical revaluation of their values, that is, through an act of the most deliberate revenge... It was the Jews who, rejecting the aristocratic value equation $($ good $=$ noble $=$ powerful $=$ beautiful $=$ happy = blessed) ventured, with awe-inspiring consistency, to bring about a reversal and held it in the teeth of their unfathomable hatred (the hatred of the powerless). ${ }^{38}$.

\footnotetext{
${ }^{36}$ Magnus and Higgins, "Nietzsche's works and their themes", 49.

${ }^{37}$ Nietzsche, On the Genealogy of Morality, 12.

${ }^{38}$ Ibid. p.18-9.
} 
In this way, the Judeo-Christian ideals rejected the conception of the good as the noble for its reverse, understanding 'themselves to be 'good' only derivatively. Judging their masters 'evil,' they concluded that they were 'good,' in the negative sense of lacking the masters' evil traits [nobility, power]. ${ }^{39}$

This "slave morality" depends upon the disposition Nietzsche calls

ressentiment. He conceives the "slave morality" of Judeo-Christianity occurring when "ressentiment itself turns creative and gives birth to values: the ressentiment of those beings who, being denied the proper response of action, compensate for it only with imaginary revenge. ${ }^{, 40}$ In this way, the slave morality adopts a point of view that "rewards" the traits of the powerless — humility, obedience, patience—and "punishes" the traits of the noble — might, wealth—but only in metaphysical world of "hereafter."

In this way, the noble as good and plebian as bad conception becomes plebian as good and noble as evil. "[H]ow different are the two words 'bad' and 'evil', although both seem to be the opposite for the same concept, 'good'! But it is not the same concept 'good'..."41 Rather, the noble good is an originator; the plebian good is only a reaction to noble "evil".

The second essay "traces the origin of bad conscience in the human disposition to cruelty." ${ }^{42}$ It stems from man's "imprisonment" in civilization, for it is at this point that instinct begins to be repressed and replaced by social values. "All instincts which are not discharged outwardly [however] turn inwards - this is what [he] call[s] the internalization of man: with it there now evolves in man what will later be called his

\footnotetext{
${ }^{39}$ Magnus and Higgins, "Nietzsche's works and their themes", 49.

${ }^{40}$ Nietzsche, On the Genealogy of Morality, 12.

${ }^{41}$ Ibid. 24.

${ }^{42}$ Magnus and Higgins, "Nietzsche's works and their themes", 49.
} 
'soul'.,"43 This turning of man against himself is a disease, according to Nietzsche.

Yet, this disease has motivated many of humanity's greatest accomplishments. Since the invention of the soul "man has been included among the most unexpected and exciting throws of dice by Heraclitus' 'great child', call him Zeus or fate - he arouses interest... as though man were not an end but just a path, an episode, a bridge, a great promise..."44

It is the "soul", then, that allows man to progress from animal to Übermensch. It is the "soul" that makes mankind the "rope fastened between animal and overman a rope over an abyss." ${ }^{45}$ The problem is that the "soul" has been hijacked by Christian thought. It has manifested the soul as a source of guilt—an indebtedness to God—that can only be alleviated through God. "Christianity's stroke of genius: none other than God sacrificing himself for man's guilt, none other than God paying himself back, God as the only one able to redeem man from what, to man himself, has become irredeemable. ${ }^{\circ 6}$ Only by rejecting this Christian belief can man again use his will to go beyond himself. "This man of the future will redeem us not just from the ideal held up till now, but also from the things which will have to arise from it... from nihilism. ${ }^{47}$

Finally, the third essay "suggests a genealogical account of yet another feature of the Christian moral worldview, its advocacy of ascetic ideals. The person who is

\footnotetext{
${ }^{43}$ Nietzsche, On the Genealogy of Morality, 61.

${ }^{44}$ Ibid. 62.

${ }^{45}$ Nietzsche, Thus Spoke Zarathustra, 7.

${ }^{46}$ Nietzsche, On the Genealogy of Morality, 68.

${ }^{47}$ Ibid. 71.
} 
self-denying, on this worldview, is seen as a kind of exemplar." ${ }^{48}$ In his analysis

Nietzsche finds that these ascetic ideals seem to be a contradiction. "For the ascetic life is a self-contradiction: here an unparalleled ressentiment rules, that of an unfulfilled instinct and power-will which wants to be master, not over something in life but over life itself..."49

Yet, this contradictory nature is only an apparent nature; for Nietzsche claims: "the ascetic ideal springs from the protective and healing instincts of a degenerating life which uses every means to maintain itself and struggles for its existence." ${ }^{50}$ That is to say that the ascetic ideal rises out of the individual who already believes that his life is fading - that life holds no more interest for him. In this way, the ascetic ideal is still a contradiction but not a self-contradiction. "[T] he situation is therefore the precise opposite of what the worshippers of this ideal imagine, - in it and through it, life struggles with death and against death, the ascetic ideal is a trick for the preservation of life." 51

But the life that the ascetic ideal preserves is not, according to Nietzsche, lively. Rather, it is geared specifically at preserving the sickly—namely those men who have lived in civilization, those with bad conscience. The ascetic ideal, then, is used as an attempt to relieve the guilt brought about by the invention of the soul. The Christian worldview blames man for their own guilt, their own sickness, and presents the adoption of the ascetic ideal as the only alleviation, the only cure. The individual is given a new reason to live, to alleviate his guilt, but at the expense of his self-esteem.

\footnotetext{
${ }^{48}$ Magnus and Higgins, "Nietzsche's works and their themes", 50.

${ }^{49}$ Nietzsche, On the Genealogy of Morality, 91.

${ }^{50}$ Ibid. 93.

51 Ibid.
} 
The ascetic ideal, then, like bad conscience and modern morality, "accomplishes a gradual poisoning of those who embrace it. Ironically, ascetic ideals offer palliatives to those who are already sick, but these palliatives themselves make the sick sicker in the long term."

What does Nietzsche suggest is the alternative to the ascetic ideal? It is not modern science. "Do not come to me with science when I am looking for the natural antagonist to the ascetic ideal... Science is not nearly independent enough for that... science itself never creates values." ${ }^{53}$ This suggests that Nietzsche seeks that which independently creates its own values. He is seeking the Übermensch. "[T]he ascetic ideal has, for the present, even in the most spiritual sphere, only one type of real enemy and injurer: these are the comedians of this ideal - because they arouse mistrust." ${ }^{, 54}$ The Übermensch are these comedians because they are able to see the meaning behind the ascetic ideals and no longer need to hold them in reverence - they alone are capable of ridiculing these ideals.

\section{Revaluation of All Values!}

This ability to ridicule, to revaluate ideals, is what Nietzsche believes to be central to the Übermensch. By examining what Nietzsche believes this revaluation calls upon, one can finally fully grasp what nihilism is for him. This section, then, will be dedicated to this examination and to defining Nietzschean nihilism.

To begin, one must recognize that the revaluation of all values has been a driving force in most of Nietzsche's works if not explicitly stated as such. "Behind his

\footnotetext{
${ }_{53}^{52}$ Magnus and Higgins, "Nietzsche's works and their themes", 51.

${ }^{53}$ Nietzsche, On the Genealogy of Morality, 120.

${ }^{54}$ Ibid. 125-6.
} 
ranging activity (for he is journeying restlessly and aimlessly, as in a desert) stands the question mark of an ever more dangerous curiosity. 'Cannot all values be overturned? ${ }^{\prime, 55}$ For Nietzsche, the values to which he directed his revaluation often were those of the Christian worldview. This is evidenced greatly by both Thus Spoke Zarathustra and On the Genealogy of Morality. The first, a parody of the most important books of the Christian faith, calls for the rise of a new way of thinking that rejects the tenets of the social view. The latter is an outright attack on the presumed "naturalness" of the tenets of Christianity.

In order for one to be capable of this revaluation, he must be of a certain mindset. He must be a "free spirit," for which Nietzsche wrote a manifesto:

You need to have become used to living on mountains - to seeing the miserable, ephemeral little gossip of politics and national self-interest beneath you. You need to have become indifferent, you need never to ask whether truth does any good, whether it will be your undoing... The sort of predilection strength has for questions that require more courage than anyone possesses today; a courage for the forbidden... Respect for yourself; love for yourself; an unconditional freedom over yourself... ${ }^{56}$

It is these free spirits, who can join Nietzsche in his "journey" for the revaluation of all values. In fact, they "already constitute a 'revaluation of all values', a living declaration of war on and victory over all old concepts of 'true' and 'untrue'.,"57

Yet, the question remains: what creates these free spirits, these Übermenschen? For Nietzsche, the answer is nihilism - the experience of being unable to interpret one's experience of the world with the existing conceptual apparatus. The act of

\footnotetext{
${ }^{55}$ Nietzsche, Human, All Too Human, 7.

${ }^{56}$ Nietzsche, The Anti-Christ, Ecce Homo, Twilight of the Idols, and Other Writings, 3.

${ }^{57}$ Ibid. 11.
} 
calling into question one's inherited conceptual apparatus is the path to the Übermensch. It is the path which Nietzsche has paved, but which he insists was brought about by the Christian worldview itself. "One can see what it was that actually triumphed over the Christian god: Christian morality itself, the concept of truthfulness that was taken ever more rigorously; the father confessor's refinement of the Christian conscience, translated and sublimated into a scientific conscience, into intellectual cleanliness at any price." ${ }^{, 58}$ The price to be paid becomes this very Christian worldview.

To put this another way, "The advent of nihilism has become necessary for our time because it represents 'the ultimate logical conclusion of our great values and ideals', and this means that we have to experience nihilism before we can find out what values these "values' really had." ${ }^{, 59}$ In order to be able to revaluate all values, then, one must first doubt their own values. It is at this point that one experiences the freedom of nihilism and "every daring of the lover of knowledge is allowed again."60

Nietzschean nihilism can be seen, then, as a bridge, a pathway, from the dualist thinking of Western metaphysics to that of the Übermensch. It is a reconditioning of the human mind such that it rejects the "happiness" invented by the last man and seeks to create its own earthly values. It is the very doubt that Nietzsche has spread with his works. It was Nietzsche's goal "to prepare us for change. He shows that humanity has a history, that it has been (de-)formed in a particular way, and that the end of the Christian-moral interpretation of the world offers the possibility of another

\footnotetext{
${ }^{58}$ Nietzsche, The Gay Science, 219.

59 Ansell-Pearson, An Introduction to Nietzsche as Political Thinker, 200.

${ }^{60}$ Nietzsche, The Gay Science, 199.
} 
beginning." ${ }^{\prime 61}$ It is a beginning wherein man can focus on the enhancement of humanity.

\section{Nietzsche's Influence on Strauss}

It is necessary before moving on to investigate the thought of Foucault to briefly show the influence that Nietzsche had on Strauss' thought. The reason this is necessary is to show that while Strauss is an esoteric nihilist he is not a Nietzschean nihilist despite being heavily influenced by Nietzsche. This argument is made in direct opposition to the likes of S. B. Drury ${ }^{62}$ and Peter Levine ${ }^{63}$ who claim that the esoteric Strauss is purely Nietzschean.

Drury saw Strauss as a Nietzschean thinker for two reasons. "First, he shares with Nietzsche a nihilistic conception of truth. Second, he voices anew one of Nietzsche's fundamental insights regarding the dangerous and detrimental nature of truth and knowledge." ${ }^{, 64}$ In regard to the first, I am inclined to agree with Drury in so far as both thinkers saw "[t]ruth [as] one thing, and what passes for truth [as] another. The latter is for the many, whereas the former is for the few; the latter is salutary and serves to preserve the herd, whereas the former is dangerous and threatens the survival of the race." ${ }^{65}$ The problem with this conception is that Drury holds that Nietzsche saw nihilism—or truth—as detrimental. As mentioned above, Nietzsche saw nihilism as detrimental only to the conceptual apparatus that it threw into doubt. For humanity,

\footnotetext{
${ }^{61}$ Ansell-Pearson, An Introduction to Nietzsche as Political Thinker, 205.

${ }^{62}$ Drury, "The Esoteric Philosophy of Leo Strauss", 315-337.

${ }^{63}$ Levine, Nietzsche and the Modern Crisis of the Humanities.

${ }^{64}$ Drury, "The Esoteric Philosophy of Leo Strauss", 333.

65 Ibid. 334.
} 
nihilism is a necessary condition that must be overcome. It is a path to a new beginning; it is an unfettering.

This is the fundamental difference between Straussian and Nietzschean nihilism. For Strauss, “[o]nly the few have the intestinal fortitude to withstand the harsh truth of nihilism",66 and therefore this "[t]ruth is not good for humans; they cannot survive without myths and illusions. The necessary connection between goodness, happiness, and truth that traditional philosophers have long fostered is an illusion, but its disruption threatens our very survival. ${ }^{, 67}$ For Nietzsche, the preservation of humanity is not a goal for which one should strive. Rather, he is led to ask "How shall human being be overcome?"68 The answer, as shown, is through nihilism.

What Nietzsche saw as a cure capable of allowing humanity to grow and enhance itself, Strauss saw as a pandemic capable of toppling civilization if revealed to the wrong people. ${ }^{69}$ In this way, Strauss and Nietzsche bookend the spectrum of nihilist thought. One takes the pessimistic view, the other takes a more optimistic view. Between them, as will be shown, lies Foucault — who takes a stance of neutrality in regards to the effects of nihilism.

\footnotetext{
${ }^{66}$ Ibid.

${ }^{67}$ Ibid.

${ }^{68}$ Nietzsche, Thus Spoke Zarathustra, 232.

${ }^{69}$ And there may be something to be said for Strauss' view considering the unfortunate misappropriation of Nietzsche's philosophy during the Third Reich.
} 
Chapter 5 - Michel Foucault

It is time now to turn attention to the works of Michel Foucault and explore his place is on the spectrum of nihilist thought. Foucault examines the human condition through the study of history in a manner very similar to Nietzsche's perspectivism. Where Nietzsche tried to find the value of "values", however, Foucault was more concerned "with what knowledge does, what power constructs (rather than represents) and how a relationship of the self to the self is invented rather than discovered." ${ }^{\prime 1}$ In other words, he attempted to explain history from the perspective of history. His path, however, leads him to a drastically different conclusion from either Strauss or Nietzsche.

\section{Foucauldian Nihilism}

Foucauldian nihilism, which will be called pure nihilism, is distinct from the previous two versions of nihilism in that it does not hold a value judgment on nihilism - that is, it does not claim that nihilism is a good or bad thing. Rather, Foucauldian nihilism presents nihilism as the machinations of human thought. Ideas, ideals, and knowledges exist, are adopted, and influence people regardless of whether they are aware of this occurrence or not. To understand this, one must first understand the evolution of Foucault's thought.

\section{Foucault's Archaeology}

Foucault's historical studies can be divided into two forms — archaeology and genealogy. The first form begins the investigation into the history of ideas "with the fact that, at any given period in a given domain, there are substantial constraints on

\footnotetext{
${ }^{1}$ Lamber and Smeyers, "Nihilism: Beyond Optimism and Pessimism", 187.
} 
how people are able to think." 2 This not only includes the limits of language, or technology, but also the limits provided by the implicit rules found in every mode of thinking.

It is these implicit rules, of which the user may be unaware, that Foucault is interested in analyzing in his archaeologies.

Foucault's idea is that the level of analysis, of what is outside the control of the individuals who actually do the thinking in a given period, is the key to understanding the constraints within which people think. So the 'history of ideas' - where this means what is consciously going on in the minds of scientists, philosophers, et al. - is less important than the underlying structures that form the context of their thinking. ${ }^{3}$

This brings about a "marginalization of the subject", or a history without the individual subject.

For Foucault, this is important because it helps to eliminate the distortions one can receive when concentrating on a subject-centered history. It prevents history from being seen as a continuous "narrative" that leads to the present. It prevents history becoming "a novel, with a plot unified by the concerns of human beings and leading to a humanly meaningful conclusion."4 Rather, Foucault's archaeologies seek to suggest that much of what the subjects thought "may have been the rather distant outcome of factors quite outside their consciousness... His project is... to offer an internal account of human thinking, without assuming a privileged status for the conscious content of that thought."

\footnotetext{
${ }^{2}$ Gutting, Foucault: A Very Short Introduction, 32.

${ }^{3}$ Ibid. 33 .

${ }^{4}$ Ibid. 34 .

${ }^{5}$ Ibid. 35 .
} 
This archaeological method is both used and developed in his earlier works:

Madness and Civilization, ${ }^{6}$ The Birth of the Clinic, ${ }^{7}$ and The Order of Things. ${ }^{8}$

However, he gives a detailed formulation in The Archaeology of Knowledge ${ }^{9}$ wherein he describes the method as:

An enterprise by which one tries to measure the mutations that operate in general in the field of history; an enterprise in which the methods, limits, and themes proper to the history of ideas are questioned; an enterprise by which one tries to throw off the last anthropological constraints; an enterprise that wishes, in turn, to reveal how these constraints could come about. ${ }^{10}$

It is an enterprise, then, with the "ability to present us with alternative modes of thinking that challenge the necessity that we find in our own modes of thought."11

The method behind this enterprise involves identifying the important rules of formation associated with the historical concept being analyzed, whether madness, medicine, or the social sciences. These rules of formation are teased out of the dispersions present when one tries to understand the unity between statements made about or in a particular field using only a single point of analysis — either, "a welldefined field of objects", "a definite, normative type of statement", "a well-defined alphabet of notions", or "the permanence of a thematic". 12

The rules of formation, then, are concerned with trying to identify some regularity amongst these dispersions. "Whenever one can describe, between a number of statements, such a system of dispersion, whenever, between objects, types of

\footnotetext{
${ }^{6}$ Foucault, Madness and Civilization.

${ }^{7}$ Foucault, The Birth of the Clinic.

${ }^{8}$ Foucault, The Order of Things..

${ }^{9}$ Foucault, The Archaeology of Knowledge.

${ }^{10}$ Ibid. 15

${ }^{11}$ Gutting, Foucault: A Very Short Introduction, 41.

${ }^{12}$ Foucault, The Archaeology of Knowledge, 31-37.
} 
statement, concepts, or thematic choices, one can define a regularity... we will say, for the sake of convenience that we are dealing with a discursive formation." ${ }^{\prime 13}$ These discursive formations are, in simpler terms, the fields of knowledge being studied. These rules of formation involve the four points of analysis listed aboveobjects, types of statement, notions, and a thematic. The formation rule of objects has as its goal " $[\mathrm{t}] \mathrm{o}$ define these objects without reference to the ground, the foundation of things, but by relating them to the body of rules that enable them to form as objects of a discourse and thus constitute the conditions of their historical appearance." ${ }^{14}$ In other words, the objects of a field of knowledge must be defined in the way the field of knowledge formed them. It cannot simply be referred to as the common definition of the objects because to do so would detach it from the field that rendered it intelligible.

In regards to the formation of forms of statements, or modes of authority, one must identify who is speaking, from which institutional site is he speaking, and the position which he occupies in relation to the various groups of objects. "It can be said that this relation between different elements (some of which are new, while others were already in existence) is effected by clinical discourse: it is this, as a practice, that establishes between them all a system of relations that is not 'really' given." 16 These enunciative modalities establish the relations that take place in a given field of knowledge and define these relations with regard to how they developed over time (instead of assuming that the relation had always been there).

\footnotetext{
${ }^{13}$ Ibid. 38 .

14 Ibid. 48.

15 Ibid. 50-2.

${ }^{16}$ Ibid. 53-4.
} 
As for the formation of concepts, it involves the grouping together of very incongruent notions but still belongs to a particular discursive formation. "[W]hat makes it possible to delimit the group of concepts, disparate as they may be... is the way in which these different elements are related to one another... It is this group of relations that constitutes a system of conceptual formation. ${ }^{, 17}$ Concepts within a discursive formation develop out of the relationship between subject and object, between object and object, between object and subject (which is distinct from the relationship between subject and object), and between subject and subject. This is clarified when one examines a particular field of knowledge. The concept of "sanity" in current usage ${ }^{18}$ within the field of psychiatry can only be fully understood when one examines how it stems out of the relationship between the "psychiatrist" and the "patient", between two "patients", between the "patient" and the "psychiatrist" and amongst "psychiatrists". In this way, the concept of "sanity" is show to be understood differently depending upon the context in which it is used - it is a diagnosis in the first instance, a comparison in the second, a request for treatment in the third, and a technical term in the fourth.

Finally, with regard to the formation rules regarding thematic choices, or strategies, Foucault is vague. He claims that in each of his archaeological studies "[t]he place, and the implications, of the strategic choices were indicated... but I did little more than locate them, and my analysis scarcely touched on their formation." 19

\footnotetext{
${ }^{17}$ Ibid. 59-60.

${ }^{18}$ For it will differ throughout time.

${ }^{19}$ Foucault, The Archaeology of Knowledge, 65.
} 
However, he does leave one with guidelines for finding these formations using the previous formation rules as guides.

And just as one must not relate the formation of objects either to words or to things, not that of statements either to the pure form of knowledge or to the psychological subject, nor that of concepts either to the structure of ideality or to the succession of ideas, one must not relate the formation of theoretical choices either to a fundamental project or to the secondary play of opinions. ${ }^{20}$

The formation of strategies, then, must not be understood as a choice between two options that had to come into conflict with each other.

Using these rules of formation, Foucault's archaeologies have an outcome similar to that of Nietzsche's works. They attempt to present the reader with "the conditions and circumstances under which the values [and facts one holds] grew up, developed, and changed." ${ }^{, 1}$ Yet, Nietzsche's effect on Foucault is not fully realized until one examines his second form of historical study_-genealogy.

\section{Foucault's Genealogy}

Foucault's genealogical method was only used in a single completed work: Discipline and Punish. ${ }^{22}$ Though other works were proposed that would also use this method, they were unfortunately never written. ${ }^{23}$ This is an important distinction because unlike his archaeologies, "there is no genealogical counterpart to the detailed retrospective methodological analysis offered in The Archaeology of Knowledge." 24 Therefore, it is necessary to examine Discipline and Punish in order to understand how the genealogical method differs from that of the archaeological method.

${ }^{20}$ Ibid. 70.

${ }^{21}$ Nietzsche, On the Genealogy of Morality, 8.

${ }^{22}$ Foucault, Discipline and Punish.

${ }^{23}$ Gutting, Foucault: A Very Short Introduction, 44.

24 Ibid. 
"The first thing [one] should notice is the important extent to which the methodology is still archaeological." ${ }^{, 25}$ It identifies imprisonment with the four archaeological categories mentioned above: objects, enunciative modalities, concepts, and strategies. ${ }^{26}$ It differs from the archaeological studies, however, in that it applies these categories not only to language but also to practices. It is "concerned, therefore, not just with the language (analysed by archaeology) through which we know the world, but with the power that changes the world.",27

This is the beginnings of the formation of what Foucault will call power/knowledge. A more in depth analysis of this concept will take place in the following section but for now it is simply enough to take note that this concept has as its origin Foucault's genealogical studies. More specifically, in Discipline and Punish, Foucault found that 'a corpus of knowledge, techniques, 'scientific' discourses is formed and becomes entangled with the practice of the power to punish."28 This is the purpose behind the genealogical method, then: to analyze a discursive formation not only from the linguistic "knowledge" it has created for itself but from the material power relations that are entangled with these knowledges.

In Discipline and Punish, Foucault used this genealogical method to analyze the history of punishment as it moved from the violent assaults on the body in the $18^{\text {th }}$ century to the form of incarcerations in the $19^{\text {th }}$ century.

What was then being formed was a policy of coercions that act upon the body, a calculated manipulation of its elements, its gestures, its behaviour. The human body was entering a machinery of power that explores it, breaks it

\footnotetext{
${ }^{25}$ Ibid. 45 .

${ }^{26}$ Ibid.

${ }^{27}$ Ibid.

${ }^{28}$ Foucault, Discipline and Punish, 23.
} 
down and rearranges it. A 'political anatomy', which was also a 'mechanics of power', was being born; it defined how one may have a hold over others' bodies, operate as one wishes, with the techniques, the speed and the efficiency that one determines. Thus discipline produces subjected and practised bodies, 'docile' bodies. ${ }^{29}$

That is to say, he found that this transition took place through the machinations of human bodies as well as human thought. This eventually leads him to claim that all such transitions - that is, all of human history — takes place through the actions of human bodies and human thought. Human thought becomes inseparable from bodyit must always be understood in the context of its effects on the body and the body's effects on it.

In this way, Foucault's genealogy is very similar to that of Nietzsche. "Nietzsche used genealogy to show that our most revered institutions and practices were 'human, all-too-human'. Foucault's genealogies likewise deconstruct, by showing their real origin, official meanings and evaluations involved in a society's self-understanding." 30 Thus, the most important distinction between Foucault's archaeologies and his genealogies is the focus on the present. The archaeologies attempted to explain how discursive formations understood themselves during a particular historical period. The genealogies "should be seen as a kind of attempt to emancipate historical knowledges from the subjection... of a theoretical, unitary, formal and scientific discourse." ${ }^{31}$ That is to say, they concerned themselves with the task of liberating human thought from the notion of continuous development.

\section{Power/Knowledge}

\footnotetext{
${ }^{29}$ Ibid. 138.

${ }^{30}$ Gutting, Foucault: A Very Short Introduction, 49.

${ }^{31}$ Foucault, Power/Knowledge, 85.
} 
Having examined both the archaeological and genealogical studies of history, it is now time to return to the conception of power/knowledge. As mentioned the notion of power/knowledge is a complex entangling of knowledge with power relations. "Far from preventing knowledge, power produces it... It was on the basis of power over the body that a physiological, organic knowledge of it became possible." ${ }^{, 32}$ Yet, it is knowledge which sustains the power that produced it and produces further power.

It is this power/knowledge which creates truth. That is to say, Foucault, like Nietzsche and Strauss argues against the objective nature of truth. He argues that "[t]ruth is a thing of this world: it is produced only by virtue of multiple forms of constraint. And it induces regular effects on power." ${ }^{33}$ By understanding truth as a worldly product, one can understand the entanglement of power and knowledge.

'Truth' is centered on the form of scientific discourse and the institutions which produce it; it is subject to constant economic and political inticement (the demand for truth, as much for economic production as for political power); it is the object, under diverse forms, of immense diffusion and consumption (circulating through apparatuses of education and information whose extent is relatively broad in the social body, not withstanding certain strict limitations); it is produced and transmitted under the control, dominant if not exclusive, of a few great political and economic apparatuses (university, army, writing, media); lastly, it is the issue of a whole political debate and social confrontation ('ideological' struggles). ${ }^{34}$

In this way, truth (or knowledge) is produced by power (scientific discourse). It, then, spurs the use and sustaining of power. Finally, power produces new truths as its nature changes through the production of knowledge.

\footnotetext{
${ }^{32}$ Ibid. 59.

${ }^{33}$ Ibid. 131.

${ }^{34}$ Ibid. 131-2.
} 
"On the other hand, [one] may find it implausible to think that power can ever produce knowledge... If, the thought goes, everything I believe is determined by the power structures of my society, how can any of my beliefs have validity except relative to the standards of that society?"35 Foucault has no argument against this, nor does he need one. His concept of power/knowledge makes it such that all truth, all knowledge, is conventional. This does not exclude his position. One will accept his position only if he is already subject to the same power regime as Foucault. ${ }^{36}$ The reason why this conclusion is not problematic for Foucault becomes apparent when one recognizes his notion of theory as a toolkit, to which I now turn.

\section{Pure Nihilism}

Foucault's form of nihilism, then, appears to be as follows: all knowledge, all fields of knowledge, are subject to their own rules of formation. These rules apply not only to the language used to understand the fields but also to the power relations intrinsic to the field. This is encapsulated in the concept of power/knowledge, which is what drives the transitions of human history. But they do so in no given directionthat is to say human history is directionless.

This leaves Foucault's theory "out in the cold" as it were, since it commits his notion of power/knowledge to the same radical relativism as any other theory of knowledge. But if one understands this theory as a toolkit, its usefulness is recovered.

The notion of theory as a toolkit means: (i) The theory to be constructed is not a system but an instrument, a logic of the specificity of power relations and the struggles around them; (ii) That this investigation can only be carried out step

\footnotetext{
${ }_{35}^{35}$ Gutting, Foucault: A Very Short Introduction, 52.

${ }^{36}$ Ibid.
} 
by step on the basis of reflection (which will necessarily be historical in some of its aspects) on given situations. ${ }^{37}$

This means that Foucault's theory of power/knowledge, like any theory of knowledge, should be viewed as an instrument to understand historical power relations and not as a system of universal knowledge. However, when this toolkit is used on individual power relations, one soon realizes that there are no systems of thought - no power relations - that escape the radical relativism of Foucault's notion of truth.

That is to say, that all power relations, when examined individually with the theory of power/knowledge, are revealed to be relative to historical circumstances. There are no eternal facts, only facts relative to the power/knowledge relation under investigation. Therefore, there is no need for Foucault to defend his theory against the claims that only those people who are under the same power regime as himself will accept his position. His theory already holds that to be so, not only for his position but for all positions.

This form of nihilism, then, is not a system of knowledge in its own right but merely the recognition that various powers/knowledges are actively influencing not only human thought but human bodies-including themselves. Life in relation to power/knowledge, then, could be seen as a struggle of "all against all.... We all fight against each other. And there is always within each of us something that fights something else. ${ }^{\prime 38}$ Out of this struggle, individuals create their truth—nihilists included.

\footnotetext{
${ }^{37}$ Foucault, Power/Knowledge, 145.

${ }^{38}$ Ibid. 208.
} 
Chapter 6-Conclusion

The goal of this work has been to show that not only is Leo Strauss an esoteric nihilist but a distinct nihilist. By seeing him as such, one gets a better understanding of the full range of nihilistic thought from positive to negative. Each version of nihilism-Straussian, Nietzschean, and Foucauldian — uses the theory for different goals. This final chapter will briefly recapitulate these three versions of nihilist thought. Finally, an argument will be made that the version of nihilism one accepts is dependent upon his outlook on the human condition.

\section{Three Types of Nihilism}

Through the course of this paper, three distinct types of nihilism have been sketched out. Each version represents a different defining point of the spectrum of nihilist thought. On the one end, there is Straussian nihilism which is indicative of pessimistic nihilism. On the other end, lies Nietzschean nihilism which is indicative of optimistic nihilism. Between them, lies Foucauldian nihilism which is neutral in its outlook. How these three forms of nihilism are representative of these positions is reiterated below.

\section{Straussian Nihilism}

Strauss sees nihilism as a truth. Yet, his view on the relationship between humanity and truth forces him to disguise this fact.

Nihilism, or the insight into the groundlessness of our ideas of law, justice, and morality, is (to use Nietzsche's phrase) a "deadly truth." We therefore are confronted with a choice between this deadly truth and a life-saving myth. Unless we are bent on self-annihilation, we should choose the life-saving myth. Truth is not good for humans; they cannot survive without myths and illusions. The necessary connection between goodness, happiness, and truth that 
traditional philosophers have long fostered is an illusion, but its disruption threatens our very survival. ${ }^{1}$

This disguise, this "noble lie", is necessary for the survival of human civilization, according to Strauss - without it there would be but chaos.

This fear, rational or otherwise, stems from the fact that Strauss sees humanity as being able to adopt the view "that every preference, however evil, base, or insane, has to be judged before the tribunal of reason to be as legitimate as any other preference." It is this consequence of nihilism that Strauss seeks to avoid. Therefore, he exoterically hides the "truth" of nihilism behind the "noble lie" of the American social religion—natural rights.

By his example, he is arguing that nihilists should not reveal their viewpoint for fear of its negative impact on society. In this way, Straussian nihilism can be known as 'closet nihilism.' It is a view that should be held only in private or, at most, in the company of fellow nihilists.

\section{Nietzschean Nihilism}

Nietzschean nihilism, on the other hand, is laid out as publicly as Straussian nihilism is hidden. This is due to Nietzsche's view that there are three forms, or stages, of nihilism. There is weak or passive nihilism, incomplete nihilism, and active nihilism. It is this latter form of nihilism which Nietzsche advocates. ${ }^{3}$ It is the passive nihilist for which Stauss" "noble lie" is written. Passive nihilism is equated with "the all-too-common psychological experience of weariness, discouragement, sense of

\footnotetext{
${ }^{1}$ Drury, "The Esoteric Philosophy of Leo Strauss", 334.

${ }^{2}$ Strauss, Natural Right and History, 42.

${ }^{3}$ Hicks, "Nietzsche, Heidegger, and Foucault: Nihilism and Beyond", 78.
} 
insecurity, and defeat. This is the experience of the disillusioned individual who has lost faith in the efficacy of traditional values and who cannot bear this life of pain and suffering without the hope and promise of a better or 'truer' world." "This is the experience of nihilism that creates the last man.

Incomplete nihilism, alternatively, can be described as a stage of transition between traditional views and active nihilism. It is where individuals have adopted an attitude of destruction "toward the body of traditional moral, political, and religious teaching and beliefs, which [they] felt were confusing, obscure, old-fashioned, and anti-progressive." ${ }^{5}$ Yet, they have not been able to take the positive steps towards active nihilism and the revaluation of all values. This is due to the fact that they simply replace the traditional faith that they have deconstructed with a faith in materialistic science. 'Most of them believed that 'science'—broadly construed to include evolution, socialism, utilitarianism, free-martketism, and so forth-would fill the place left empty by traditional moral and religious beliefs." ${ }^{, 6}$ In this way, incomplete nihilists, like passive nihilists, seek an "ought" — an ultimate order of the world that bestows value and purpose onto reality.

It is this "ought" that Nietzsche and active nihilists seek to dissolve. It is active nihilism that creates the Übermensch — the individual capable of creating "earthly values". Nietzschean nihilism can be seen, then, as the rejection of the dualist thinking of Western metaphysics and the adoption of the earthly values of the Übermensch. It is a reconditioning of the human mind such that it rejects the "happiness" invented by

\footnotetext{
${ }^{4}$ Ibid.

${ }^{5}$ Ibid. 79.

${ }^{6}$ Ibid. 80.
} 
the last man and seeks to create its own earthly values. It is by this definition of nihilism that Nietzsche is a nihilist. He seeks to dissolve the "ought" of Western and Christian morality and advocates the adoption of "earthly values". He brings nihilism to the forefront in order to have the Übermensch overcome passive and incomplete nihilism to become active nihilists.

The consequences of nihilism, for Nietzsche, do not hold the same negative connotations as they do for Strauss. Where Strauss saw chaos and destruction, Nietzsche found, at worse, stagnation and, at best, creation. Übermensch nihilism, then, is the optimistic view that nihilism will lead to the creation of values that enhance humanity.

\section{Foucauldian Nihilism}

Finally, there is Foucauldian nihilism. This could also be referred to as pure nihilism, since it holds that all principles, including nihilism, are derivatives and creators of power relations. For this reason, "Foucault disconcerts."7 He negates the traditional efficacy of moral, religious, philosophical, and political theory, while refusing to replace them with any other universal system of knowledge. He does not fall into the category of the Übermensch because he does not create his own values. He does not hold that one can create values. Rather, they are "imparted" on the body ${ }^{8}$ through the web of power/knowledge in which one exists.

What Foucauldian nihilism leaves one with is the knowledge that one is a product of this web of power/knowledge into which one is born. Whatever "truth" one

\footnotetext{
${ }^{7}$ Taylor, Philosophy and the Human Sciences Philosophical Papers 2, 152.

${ }^{8}$ Since Foucault removes the "thinking subject" from the picture.
} 
holds, he does so because of the "victories" won in the struggle of powers/knowledges that takes place upon the body. The individual who recognizes Foucauldian nihilism understands that he does so out of the circumstances of his personal history. He, at once, lives his life with the recognition of the power/knowledge web that envelopes him and with the recognition that participation within this web is compulsory.

Foucauldian nihilism is a theory that holds that "there is no order of human life, or way we are, or human nature, that one can appeal to in order to judge or evaluate between ways of life. There are only different orders imposed by men on primal chaos." 9 These orders are the powers/knowledges that humanity through history has created and imposed on itself. They include the traditional theories, they include Straussian nihilism, they include Nietzschean nihilism, and they most certainly include Foucauldian nihilism.

\section{Nihilism \& the Human Condition}

What bearing, then, does this distinction have on field of political theory? The answer, put simply, is that by recognizing these three forms of nihilism one recognizes that theory can play one of three roles in society. This role in society is determined, ultimately, by the theorist's outlook on the human condition-on how he believes humanity would react to the notion of nihilism.

If one were to hold, as Strauss does, that "belief" is essential to the survival of human civilization and that "[t]he inescapable consequence of nihilism is fanatical obscurantism," 10 then one would be wise to hide nihilism from humanity with beliefs.

\footnotetext{
${ }^{9}$ Taylor, Philosophy and the Human Sciences Philosophical Papers 2, 178.

${ }^{10}$ Strauss, Natural Right and History, 6.
} 
That is to say, that one who holds this view of humanity as believers must develop beliefs for humanity lest they learn the "truth" of nihilism. Political theory, for this individual, is the producer of "noble lies". The political theorist is the Platonic philosopher - one who creates the laws for the people in secret and leads them to believe in their value.

If, however, one were to hold that "belief" is stagnating or even poisoning humanity, then one would have to reject the objects of belief — be they religion, philosophy, or science. One must not only reject belief but create their own values-values that are of this world and not some "truer" world. Political theory, in this view, becomes the means by which one "revaluates all values" and creates new values for the enhancement of humanity. The political theorist is the Übermensch—one who has overcome the beliefs that were instilled in him by society and has created his own values by which to live.

Finally, if one were to hold that all "belief" is the "truth" which has been created through power/knowledge relations through history, then one recognizes that any theory one produces is a product of the power structures operating on him. For this theorist,

We [as humanity] have become something. Questions of truth and freedom can arise for us in the transformations we undergo or project. In short, we have a history. We live in time not just self-enclosed in the present, but essentially related to a past which has helped define our identity, and a future which puts it again in question. ${ }^{11}$

\footnotetext{
${ }^{11}$ Taylor, Philosophy and the Human Sciences Philosophical Papers 2, 182.
} 
Political theory in this view is the process by which powers/knowledges exert their influence on the bodies of the theorists. The political theorist is the one who embodies the "victory" of a power/knowledge and promotes its "truth" whatever it may be. A Foucauldian theorist, then, would explore the history of political powers/knowledges using Foucault's example as his toolkit.

Ultimately, the deciding factor of which view one will adopt on political theory, on nihilism, is the individual's personal history. If he feels that he does not have the ability to make significant change, that there are far more powerful influences in the world, then he will adopt Straussian nihilism. He will know that the views he is promoting do not hold some privileged status as objective truth but that they are the least of all evils.

If he feels that his life is in his own hands, that he can make effective change in the world, than he will adopt Nietzschean nihilism. He will reject those teachings that were instilled in him and adopt those he creates himself. He will do all that he can to better himself.

If he understands that he is the product of his circumstance, that all that he holds to be true is that which has gain the most influence over him, then he is influenced by Foucauldian nihilism. The Foucauldian nihilist is so simply because there is not other option available to him due to the power/knowledge structures in which he exists. He recognizes his place in history and he lives. 
References

Ansell-Pearson, Keith. An Introduction to Nietzsche as Political Thinker. Cambridge: Cambridge University Press, 1994.

Aquinas, Thomas. The Political Ideas of St. Thomas Aquinas. Edited and translated by Dino Bigongiari. New York: Hafner Publishing Company, 1953.

—. Selected Political Writings. Edited by A. P. D'Entrèves. Translated by J. G. Dawson. Oxford: Basil Blackwell, 1959.

Aristotle. Politics. Benjamin Jowett, trans. Mineola, New York: Dover Publications, 2000.

Behnegar, Nasser. Leo Strauss, Max Weber, and the Scientific Study of Politics. Chicago: University of Chicago Press, 2003.

Danto, Arthur C. Nietzsche as Philosopher. New York: Columbia University Press, 2005.

Drury, S. B. “The Esoteric Philosophy of Leo Strauss". Political Theory, Vol. 13, No. 3 (Aug. 1985).

Foucault, Michel. Madness and Civilization. Translated byRichard Howard. New York: Vintage Books, 1965.

- The Order of Things. Translated by Alan Sheridan. New York: Vintage Books, 1970.

- The Archaeology of Knowledge. Translated by A. M. Sheridan Smith. New York: Pantheon Books, 1972.

—. The Birth of the Clinic. Translated by A. M. Sheridan Smith. New York: Vintage Books, 1973.

- Power/Knowledge. Edited by Colin Gordon. Translated by Colin Gordon, Leo Marshall, John Mepham, Kate Soper. New York: Pantheon Books, 1980.

_. Discipline and Punish. Translated by Alan Sheridan. New York: Vintage Books, 1995.

Gutting, Gary, ed. The Cambridge Companion to Foucault. Cambridge: Cambridge University Press, 1994. 
Gutting, Gary. Foucault: A Very Short Introduction. Oxford: Oxford University Press, 2005.

Hicks, Steven V. "Nietzsche, Heidegger, and Foucault: Nihilism and Beyond" in Foucault and Heidegger, edited by Alan Milchman and Alan Rosenberg. Minneapolis: University of Minnesota Press, 2003.

Higgins, Kathleen Marie. Nietzsche's Zarathustra. Philadelphia: Temple University Press, 1987.

Kant, Immanuel. Critique of Pure Reason. Translated by Norman Kemp Smith, New York: Palgrave Macmillan, 2003.

Klosko, George. The Development of Plato's Political Theory. New York: Methuen, 1986.

Kraut, Richard. Aristotle: Political Philosophy. Oxford: Oxford University Press, 2002.

Lamber, Bert and Paul Smeyers. "Nihilism: Beyond Optimism and Pessimism". In Studies in Philosophy and Education, Vol. 22, No. 3-4 (May 2003).

Lampert, Laurence. Leo Strauss and Nietzsche. Chicago: The University of Chicago Press, 1996.

Levine, Peter. Nietzsche and the Modern Crisis of the Humanities. Albany: State University of New York Press, 1995.

Magnus, Bernd and Kathleen M. Higgins. "Nietzsche's works and their themes". In The CambridgeCompanion to Nietzsche. Edited by Bernd Magnus and Kathleen M. Higgins. Cambridge: Cambridge Universtiy Press, 1996

McAlister, Ted V. Revolt Against Modernity. Lawrence, Kansas: University Press of Kansas, 1996.

Nietzsche, Friedrich. Beyond Good and Evil. In The Philosophy of Nietzsche, edited by Willard Huntington Wright. New York: The Modern Library, 1927.

- Human, All Too Human. Translated by Marion Faber with Stephan Lehmann. Lincoln: University of Nebraska Press, 1984.

- On the Genealogy of Morality. Edited by Keith Ansell-Pearson. Translated by Carol Diethe. Cambridge: Cambridge University Press, 1994. 
- The Gay Science. Edited by Bernard Williams. Translated by Josefine Nauckhoff and Adrian del Caro. Cambridge: Cambridge University Press, 2001.

- The Anti-Christ, Ecce Homo, Twilight of the Idols, and Other Writings. Edited by Aaron Ridley and Judith Norman. Translated by Judith Norman. Cambridge: Cambridge University Press, 2005.

—. Thus Spoke Zarathustra. Edited by Adrian del Caro and Robert B. Pippin. Translated by Adrian del Caro. Cambridge: Cambridge University Press, 2006.

Plato. The Republic and Other Works. Translated by B. Jowett. Garden City, New York: Anchor Book, 1973.

—. Statesman. Edited by Julia Annas and Robin Waterfield. Translated by Robin Waterfield. Cambridge: Cambridge University Press, 1995.

—. Laws. Translated by Benjamin Jowett. Mineola, New York: Dover Publications, 2006.

Solomon, Robert C. "Nietzsche ad hominem: Prespectivism, personality and ressentiment", in The Cambridge Companion to Nietzsche, edited by Bernd Magnus and Kathleen M. Higgins. Cambridge: Cambridge Universtiy Press, 1996.

Strauss, Leo. Natural Right and History. Chicago: The University of Chicago Press, 1950.

- Persecution and the Art of Writing. Chicago: University of Chicago Press, 1952.

—. What Is Political Philosophy? Glencoe, Illinois: The Free Press, 1959.

__. "Note on the Plan of Nietzsche's Beyond Good and Evil". In Studies in Platonic Political Philosophy. Chicago: The University of Chicago Press, 1983.

__. "German Nihilism.” Edited by David Janssens and Daniel Tanguay. Interpretations. Vol. 26, No. 3 (Spring 1999).

Taylor, Charles. Philosophy and the Human Sciences Philosophical Papers 2. Cambridge: Cambridge University Press, 1985.

Zuckert, Catherine and Michael. The Truth about Leo Strauss. Chicago: The University of Chicago Press, 2006. 